\title{
Description of Nola estonica sp. nov., with comparison to $N$. aerugula and $N$. atomosa stat. rev. (Lepidoptera, Nolidae, Nolinae)
}

\author{
ERKI ÕUNAP ${ }^{1,2^{*}}$, SEI-WOONG CHOI ${ }^{3}$, ALEXEY MATOV $^{4} \&$ TOOMAS TAMMARU ${ }^{1,5}$ \\ ${ }^{1}$ Institute of Ecology and Earth Sciences, University of Tartu, Vanemuise 46, 51014 Tartu, Estonia; \\ ${ }^{2}$ Institute of Agricultural and Environmental Sciences, Estonian University of Life Sciences, Fr.R.Kreutzwaldi 1, 51006, Tartu, Estonia. \\ ${ }^{3}$ Department of Environmental Education, Mokpo National Unviersity, 1666 Youngsan-ro, Muan, 58554 Jeonnam, South Korea. \\ झ"choisw@mokpo.ac.kr; ㄴttps://orcid.org/0000-0001-6326-399X \\ ${ }^{4}$ Zoological Institute, Russian Academy of Sciences, Universitetskaya emb., 1, 199034, Saint-Petersburg, Russia. \\ "'Alexey.Matov@zin.ru; ㄴ. https://orcid.org/0000-0002-6066-6440

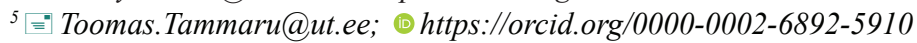 \\ *Corresponding author. ఏ" erki.ounap@ut.ee; @ https://orcid.org/0000-0001-6489-0055
}

\begin{abstract}
Nola estonica Õunap sp. nov. (Lepidoptera, Nolidae, Nolinae) is described based on type material from Estonia. The lectotype is designated for Glaphyra atomosa Bremer, 1861, which is reinstated from a subspecies of Nola aerugula (Hübner, [1793]) to a full species: Nola atomosa (Bremer, 1861) stat. rev. The status of these three taxa as separate species is supported by the results of phylogenetic analysis of DNA barcodes, as well as external and genital morphology of adult specimens. Two new synonyms are established as follows: Nola atomosa (Bremer, 1861) = Nola candidalis Staudinger, 1892 syn. nov. and Nola shin Inoue, 1982 syn. nov. N. estonica occurs sympatrically with $N$. aerugula in Estonia, and with $N$. atomosa in South Korea and easternmost Russia. While the available data suggest a disjunct distribution of $N$. estonica (eastern Europe and the temperate Far East), it appears highly possible that the species has a wide transpalaearctic distribution.
\end{abstract}

Key words: Nola, taxonomy, Palaearctic, DNA barcode

\section{Introduction}

The diverse genus Nola Leach, [1815] has a worldwide distribution (Fibiger et al. 2009), with more than 200 species known from Eurasia and Africa (Hacker et al. 2012, László et al. 2014). In the taxonomically less comprehensively studied parts of the world, new Nola species are still regularly discovered (e.g. László et al. 2014, Da et al. 2021). Even after compiling their major revision of African Nolini, Hacker et al. (2012) predicted that tens of African species still await description. In Europe, however, the species composition of Nola is better understood. The most recently described European species is N. ronkayorum Beshkov, 2006. Subsequently, Nupponen \& Fibiger (2006) reported the presence of an overlooked species, $N$. crambiformis Rebel, 1902 on the eastern margin of Europe. Further changes in the list of European Nola have resulted from revising already known taxa. As a result of their major taxonomic work, Fibiger et al. (2009) reported 17 Nola species from Europe, while subsequent revision by Hacker et al. (2012) elevated this number to 18. To our knowledge, no changes in the list of European Nola have been made thereafter.

The present study was initiated when one of the authors (TT) noticed unusual light-coloured specimens of Nola of Estonian origin, which he suspected to be distinct from Nola aerugula (Hübner, [1793]), a common species in the country. Besides the deviating external appearance, it was considered notable that such moths had always been collected as singletons with no typically looking $N$. aerugula present in the catch. DNA barcoding (Hebert et al. 2004) revealed that these moths carried a COI haplotype strongly differing from that of $N$. aerugula. A subsequent search revealed that this unusual form is abundant in at least one locality in southeastern Estonia, where numerous specimens were collected in late July and early August 2020, together with several individuals of $N$. aerugula. 
We thereafter performed a comprehensive literature search covering all known Palaearctic species to clarify the status of these moths. The only taxon resembling the light Estonian specimens was N. aerugula atomosa (Bremer, 1861), the eastern subspecies of $N$. aerugula, which is distributed in the Russian Far East, Northern China, Korea, and Japan (Oh 2001, Matov 2019). Therefore, a few specimens of $N$. aerugula atomosa from South Korea were also subjected to DNA barcoding, which revealed that these significantly differed from both N. aerugula and the problematic Estonian taxon. Moreover, DNA barcodes demonstrated that the unknown taxon from Estonia occurs in South Korea as well. To resolve the taxonomic status of the two species present in the Eastern Palaearctic region, the type material of Glaphyra atomosa Bremer, 1861 was examined.

The purpose of the current article is to describe the problematic taxon as a new species, and to revise the status of Glaphyra atomosa, which is currently treated as a subspecies of Nola aerugula.

\section{Material and methods}

\section{Specimens}

As the initial results of DNA barcoding indicated that the unknown taxon from Estonia is related to N. aerugula, we concentrated on this species and taxa morphologically closest to it. In total, about 200 specimens were studied. The material was obtained from the following collections

IZBE: Institute of Agricultural and Environmental Sciences, Estonian University of

Life Sciences (former Institute of Zoology and Botany), Tartu, Estonia

MNUEE: Insect collection in the Environmental Education lab, Mokpo National University, South Korea

RCEÕ: Research Collection of Erki Õunap, Tartu, Estonia

RCAT: Research Collection of Andro Truuverk, Tartu, Estonia

RCIT: Research Collection of Imre Taal, Tartu, Estonia

RCTT: Research Collection of Toomas Tammaru, Tartu, Estonia

TUZ: Natural History Museum, University of Tartu.

ZISP: Zoological Institute RAS, St. Petersburg, Russia

ZMH: Zoological Museum Hamburg, Germany

\section{Morphological study}

Imagoes from Estonian collections were photographed using a Canon EOS 700D DSLR camera equipped with a Canon EF 100mm f/2.8L USM IS objective. Helicon Remote software was used for a series of multiple gradually focused images, which were thereafter stacked together using the Helicon Focus version 7.6.1 software. Specimens from coll. MNUEE were photographed using a Nikon D300 DSLR camera equipped with an AF-S Micro-Nikkor $105 \mathrm{~mm} \mathrm{f} / 2.8 \mathrm{G}$ IF-ED objective. Material from coll. ZISP was photographed with a Canon PowerShot A495 digital camera with its standard objective. Images were edited and compiled into plates using Adobe Photoshop CS3 software.

Abdomens of the moths selected for dissection $(n=33)$ were detached from the thorax and macerated in a $15 \%$ solution of $\mathrm{KOH}$ for 20 hours at room temperature or 20 minutes by boiling, followed by neutralization and washing in distilled water. Thereafter, abdomens were cut open along pleurites and genitalia were separated. Scales and loose hairs were brushed off, and both genitalia and abdominal sclerites were inserted into $96 \%$ ethanol for 5 minutes before being mounted into euparal. Slides were photographed several weeks later when euparal had solidified. The built-in digital camera of a Leica S9i stereomicroscope was used to photograph genitalic slides of the material from Estonian collections and coll. MNUEE. Genitalic slides from coll. ZISP were photographed using a Leica MZ95 stereomicroscope equipped with a Leica DFC290 digital camera. Images were edited and compiled into plates using Adobe Photoshop CS3 software. Terminology used follows Hacker et al. (2012) and Kristensen (1999).

\section{Molecular study}

Altogether 44 specimens from 9 localities were subjected to molecular study, 38 from Estonia (6 localities) and 6 from South Korea (3 localities). Genomic DNA was extracted from one or two crushed legs of each specimen using DNEasy Blood \& Tissue Kit (Quiagen N.V., Venlo, Netherlands) following the manufacturer's instructions. A standard barcoding fraction (658 bp) of the mitochondrial COI gene (Hebert et al. 2004) was sequenced, with reaction protocols being different for Estonian and South Korean material. 
Estonia: PCR was performed in a total volume of $20 \mu \mathrm{l}$, with the reaction mixture containing $1 \mathrm{X}$ BD Advantage 2 PCR buffer, 1U BD Advantage 2 Polymerase mix (BD Biosciences, San Jose, USA), 0.2 mM dNTP (Thermo Scientific, Pittsburgh, USA), 5 pmol of primers cov-1f (5'-TCGCTTATTATTCAGCCATTTTATT-3') (Õunap et al. 2008) and nan (5'-CCCGGTAAAATTAAAATATAAACT-3') (Õunap et al. 2005), and 1-2 ng of purified genomic DNA. One sample failed to amplify with primers cov-1f and nan, and the latter was replaced by cov-1r (5'-CTGCACCATTTTCTACAATTCTTCT-3') (Õunap et al. 2008) to obtain a 306 bp fragment of COI from the 5' end of the barcoding fraction. PCR was performed on a T1 thermocycler (Biometra, Göttingen, Germany) and the cycling parameters were: a 2-min denaturing step at $94^{\circ} \mathrm{C}$, followed by 35 cycles of $30 \mathrm{~s}$ at $94^{\circ} \mathrm{C}, 30 \mathrm{~s}$ at $50^{\circ} \mathrm{C}$ and $60 \mathrm{~s}$ at $68^{\circ} \mathrm{C}$ with a subsequent $7-\mathrm{min}$ final extension at $68^{\circ} \mathrm{C}$. PCR products were visualized on a $1.6 \%$ agarose gel and $10 \mu \mathrm{l}$ of the PCR solution was treated with FastAP thermosensitive alkaline phosphatase and exonuclease I (Thermo Scientific). One unit of both enzymes was added to the PCR solution, which was incubated for 15 min at $37^{\circ} \mathrm{C}$, followed by $15 \mathrm{~min}$ inactivation at $80^{\circ} \mathrm{C}$. The DNA cycle sequencing was performed in a total volume of $10 \mu \mathrm{l}$ using BigDye ${ }^{\circledR}$ Terminator v3.1 Cycle Sequencing Kit (Applied Biosystems, Foster City, CA). Cycling conditions were: 33 cycles of $20 \mathrm{~s}$ at $95^{\circ} \mathrm{C}, 20 \mathrm{~s}$ at $45^{\circ} \mathrm{C}$ and $60 \mathrm{~s}$ at $60^{\circ} \mathrm{C}$. Both DNA strands were sequenced with 2 pmol of primers and sequences were resolved by 3730xl DNA Analyzer automated sequencer (Applied Biosystems) in Estonian Biocentre (Tartu, Estonia).

South Korea: For amplification, a standard pair of barcoding primers LCO1490 (5'GGTCAACAAATCATAAAGATATTGG-3') and HCO2198 (5'-TAAACTTCAGGGTGACCAAAAAATCA3') (Folmer et al., 1994) was used. The PCR was conducted using FastMix Frenche PCR kits (i-Taq; iNtRon Biotechnology, Korea) under the following conditions: initial denaturation for $3 \mathrm{~min}$ at $94^{\circ} \mathrm{C}$, followed by 30 cycles of $94^{\circ} \mathrm{C}$ for $1 \mathrm{~min}, 50^{\circ} \mathrm{C}$ for $30 \mathrm{sec}$, and $72^{\circ} \mathrm{C}$ for $1 \mathrm{~min}$, with a subsequent final $7 \mathrm{~min}$ extension at $72^{\circ} \mathrm{C}$. Gel electrophoresis for visualizing PCR products was carried out using $1 \times$ TAE buffer on 1\% agarose gel with Top Green Nucleic Acid Gel Stain (LED; Genomic Base, Korea) for 15 min at 135V. The obtained PCR products were purified with a PCR purification kit (iNtRON) and were sequenced with forward and reverse primers (GenoTech Korea).

\section{Phylogenetic analysis}

Consensus sequences were created with Geneious R7 (Biomatters Ltd, Auckland, New Zealand). In addition to the DNA barcodes of 44 specimens originally sequenced in this study, a dataset comprising 146 specimens of 11 Palaearctic Nola species was downloaded from the public data portal of Barcode of Life Data Systems (http://www. boldsystems.org/index.php) (referred to as BOLD hereinafter). Meganola albula (Denis \& Schiffermüller, 1775) and M. strigula (Denis \& Schiffermüller, 1775) were used as outgroup, thus the total size of the data matrix was 192 DNA barcodes. The BOLD sequence IDs and GenBank accession codes for sequences used are presented in Table 1. All sequences were assembled into a data matrix in BioEdit 7.0.5.2 (Hall 1999) and aligned using ClustalW (Thompson et al. 1994). Both uncorrected pairwise genetic distances between the studied specimens and phylogenetic tree implementing neighbor-joining algorithm were constructed using MEGA6 (Tamura et al. 2013).

TABLE 1. DNA barcodes used in this study. BOLD: sequence ID in BOLD Systems database. GenBank: sequence accession code in NCBI GenBank.

\begin{tabular}{|c|c|c|c|c|}
\hline Species & BOLD & GenBank & Sample ID & Country \\
\hline Meganola albula & ABOLB409-15 & & KLM Lep 02594 & Austria \\
\hline Meganola strigula & ABOLA529-14 & & TLMF Lep 16216 & Austria \\
\hline Nola aerugula & ABOLD146-16 & & KLM Lep 06131 & Austria \\
\hline Nola aerugula & ABOLD280-16 & & TLMF Lep 20883 & Austria \\
\hline Nola aerugula & ABOLD329-16 & & TLMF Lep 20932 & Austria \\
\hline Nola aerugula & ABOLD350-16 & & TLMF Lep 20953 & Austria \\
\hline Nola aerugula & DEEUR713-16 & & TLMF Lep 19143 & Austria \\
\hline Nola aerugula & GBLAB623-13 & & BC ZSM Lep 75394 & Germany \\
\hline Nola aerugula & GBLAF588-14 & & BC ZSM Lep 82294 & Germany \\
\hline Nola aerugula & GWOSI793-10 & JN284309 & BC ZSM Lep 49199 & Germany \\
\hline
\end{tabular}


TABLE 1. (Continued)

\begin{tabular}{|c|c|c|c|c|}
\hline Species & BOLD & GenBank & Sample ID & Country \\
\hline Nola aerugula & GWOTD002-12 & KX040562 & BC ZSM Lep 48218 & Hungary \\
\hline Nola aerugula & GWOTD003-12 & KX041117 & BC ZSM Lep 48219 & Hungary \\
\hline Nola aerugula & GWOTD198-12 & KX040866 & BC ZSM Lep 48414 & Germany \\
\hline Nola aerugula & LEASS852-17 & & TLMF Lep 22500 & Austria \\
\hline Nola aerugula & LEAST280-17 & & TLMF Lep 22878 & Austria \\
\hline Nola aerugula & LEATH348-14 & & TLMF Lep 15560 & Italy \\
\hline Nola aerugula & LEATH352-14 & & TLMF Lep 15564 & Italy \\
\hline Nola aerugula & LEFIA1248-10 & GU828670 & MM01776 & Finland \\
\hline Nola aerugula & LEFIC652-10 & HM872473 & MM04599 & Finland \\
\hline Nola aerugula & LEFID584-10 & HM873349 & MM06590 & Finland \\
\hline Nola aerugula & LON4192-16 & & NHMO-DAR-10136 & Norway \\
\hline Nola aerugula & NLLEA1277-14 & & RMNH.INS.538621 & Netherlands \\
\hline Nola aerugula & NOENO375-17 & & BC_LSNOE_Lep_00375 & Austria \\
\hline Nola aerugula & ODOPE702-11 & KX040566 & BC ZSM Lep 50343 & Germany \\
\hline Nola aerugula & TTNFS200-09 & & FG200 & Serbia \\
\hline Nola aerugula & NOLAE001-21 & OL539556 & IZBE1137193 & Estonia \\
\hline Nola aerugula & NOLAE002-21 & OL539557 & IZBE1137194 & Estonia \\
\hline Nola aerugula & NOLAE003-21 & OL539558 & IZBE1137195 & Estonia \\
\hline Nola aerugula & NOLAE004-21 & OL539559 & IZBE1137196 & Estonia \\
\hline Nola aerugula & NOLAE005-21 & OL539560 & IZBE1137197 & Estonia \\
\hline Nola aerugula & NOLAE006-21 & OL539561 & IZBE1137198 & Estonia \\
\hline Nola aerugula & NOLAE007-21 & OL539562 & IZBE1137199 & Estonia \\
\hline Nola aerugula & NOLAE008-21 & OL539563 & TUZ300202 & Estonia \\
\hline Nola aerugula & NOLAE009-21 & OL539564 & TUZ300203 & Estonia \\
\hline Nola aerugula & NOLAE010-21 & OL539565 & TUZ300204 & Estonia \\
\hline Nola aerugula & NOLAE011-21 & OL539566 & TUZ300205 & Estonia \\
\hline Nola aerugula & NOLAE012-21 & OL539567 & TUZ300206 & Estonia \\
\hline Nola atomosa & NOLAE013-21 & OL539568 & MNU NE2 & South Korea \\
\hline Nola atomosa & NOLAE014-21 & OL539569 & MNU NE3 & South Korea \\
\hline Nola cicatricalis & ABOLC094-16 & & TLMF Lep 20127 & Austria \\
\hline Nola cicatricalis & ABOLC132-16 & & TLMF Lep 20165 & Austria \\
\hline Nola cicatricalis & DEEUR714-16 & & TLMF Lep 19144 & Austria \\
\hline Nola cicatricalis & EII636-15 & & LC01128-26837-F06 & Czech Republic \\
\hline Nola confusalis & ABOLB407-15 & & KLM Lep 02592 & Austria \\
\hline Nola confusalis & CGUKA089-09 & & UKLB1H07 & United Kingdom \\
\hline Nola confusalis & CGUKA097-09 & & UKLB2A03 & United Kingdom \\
\hline Nola confusalis & CGUKB759-09 & & UKLB19F08 & United Kingdom \\
\hline Nola confusalis & CGUKD203-09 & KX043376 & UKLB35A10 & United Kingdom \\
\hline Nola confusalis & GBLAA1140-15 & & BC ZSM Lep 86646 & Germany \\
\hline Nola confusalis & GBLAC1055-13 & & BC ZSM Lep 77346 & Germany \\
\hline Nola confusalis & GBLAF286-14 & & BC ZSM Lep 81992 & Germany \\
\hline Nola confusalis & GBLGC180-12 & & BC ZSM Lep R 21130 & Germany \\
\hline Nola confusalis & GBLGC188-12 & & BC ZSM Lep R 21138 & Germany \\
\hline
\end{tabular}


TABLE 1. (Continued)

\begin{tabular}{|c|c|c|c|c|}
\hline Species & BOLD & GenBank & Sample ID & Country \\
\hline Nola confusalis & GWOR3846-09 & JF415813 & BC ZSM Lep 21130 & Germany \\
\hline Nola confusalis & GWOR3851-09 & JF415814 & BC ZSM Lep 21135 & Germany \\
\hline Nola confusalis & GWOR3854-09 & JF415815 & BC ZSM Lep 21138 & Germany \\
\hline Nola confusalis & GWOR3975-09 & JF415816 & BC ZSM Lep 21259 & Germany \\
\hline Nola confusalis & GWOR4211-09 & JF415812 & BC ZSM Lep 21495 & Germany \\
\hline Nola confusalis & GWORZ089-10 & HM913995 & BC ZSM Lep 30445 & Italy \\
\hline Nola confusalis & LEAFN669-13 & & RMNH.INS.544520 & Netherlands \\
\hline Nola confusalis & LEATA182-13 & & TLMF Lep 09599 & Austria \\
\hline Nola confusalis & LEFIG103-10 & HM875783 & MM13887 & Finland \\
\hline Nola confusalis & NLLEA1244-14 & & RMNH.INS.538567 & Netherlands \\
\hline Nola confusalis & NLLEA318-12 & KX049324 & RMNH.INS.538933 & Netherlands \\
\hline Nola confusalis & NOENO503-17 & & BC_LSNOE_Lep_00503 & Austria \\
\hline Nola confusalis & PHLAC648-10 & JF860215 & TLMF Lep 02683 & Italy \\
\hline Nola confusalis & PHLAE329-11 & JN284314 & TLMF Lep 04644 & Austria \\
\hline Nola confusalis & ABOLD281-16 & & TLMF Lep 20884 & Austria \\
\hline Nola confusalis & CGUKA295-09 & KX043750 & UKLB4B02 & United Kingdom \\
\hline Nola confusalis & CGUKA627-09 & KX043854 & UKLB7F05 & United Kingdom \\
\hline Nola confusalis & CGUKD263-09 & KX042890 & UKLB35F10 & United Kingdom \\
\hline Nola confusalis & FBLMS297-09 & GU654850 & BC ZSM Lep 23242 & Germany \\
\hline Nola confusalis & FBLMU519-09 & HM391846 & BC ZSM Lep 27169 & Germany \\
\hline Nola confusalis & GBLAA1019-14 & & BC ZSM Lep 83675 & Germany \\
\hline Nola confusalis & GBLAA1020-14 & & BC ZSM Lep 83676 & Germany \\
\hline Nola confusalis & GBLAC522-13 & & BC ZSM Lep 78143 & Germany \\
\hline Nola confusalis & GBLGC185-12 & & BC ZSM Lep R 21135 & Germany \\
\hline Nola confusalis & GWOR3976-09 & JF415810 & BC ZSM Lep 21260 & Germany \\
\hline Nola confusalis & GWOR4210-09 & JF415811 & BC ZSM Lep 21494 & Germany \\
\hline Nola confusalis & GWORK503-09 & GU655899 & BC ZSM Lep 21833 & Germany \\
\hline Nola confusalis & GWOTD208-12 & KX041113 & BC ZSM Lep 48424 & Germany \\
\hline Nola confusalis & LEATA183-13 & & TLMF Lep 09600 & Austria \\
\hline Nola confusalis & LEFIC298-10 & HM872142 & MM03773 & Finland \\
\hline Nola confusalis & LEFID957-10 & HM873707 & MM07911 & Finland \\
\hline Nola confusalis & LENOA1188-11 & KX045073 & LN-BD0711 & France \\
\hline Nola confusalis & LENOA1189-11 & KX047376 & LN-BD0712 & France \\
\hline Nola confusalis & LON4191-16 & & NHMO-DAR-10135 & Norway \\
\hline Nola confusalis & LON7218-18 & & KBE 2018484 & Croatia \\
\hline Nola confusalis & PHLAA672-09 & HM426073 & TLMF Lep 00712 & Italy \\
\hline Nola cristatula & ABOLB411-15 & & KLM Lep 02596 & Austria \\
\hline Nola cristatula & DEEUR712-16 & & TLMF Lep 19142 & Austria \\
\hline Nola cristatula & FBLMU065-09 & HQ955220 & BC ZSM Lep 25575 & Germany \\
\hline Nola cristatula & FBLMU521-09 & HM391847 & BC ZSM Lep 27171 & Germany \\
\hline Nola cristatula & FBLMV291-09 & GU707341 & BC ZSM Lep 28271 & Germany \\
\hline Nola cristatula & GBLAC722-13 & & BC ZSM Lep 77773 & Germany \\
\hline Nola cristatula & GBLAD431-14 & & BC ZSM Lep 77957 & Germany \\
\hline
\end{tabular}


TABLE 1. (Continued)

\begin{tabular}{|c|c|c|c|c|}
\hline Species & BOLD & GenBank & Sample ID & Country \\
\hline Nola cristatula & GBLAD543-14 & & BC ZSM Lep 78069 & Germany \\
\hline Nola cristatula & GBLGC186-12 & & BC ZSM Lep R 21136 & Germany \\
\hline Nola cristatula & GWOR3852-09 & JF415817 & BC ZSM Lep 21136 & Germany \\
\hline Nola cristatula & GWORE2040-09 & HM393511 & BC ZSM Lep 22438 & Germany \\
\hline Nola cristatula & GWORK523-09 & JF415400 & BC ZSM Lep 21853 & Germany \\
\hline Nola cristatula & GWORL464-09 & GU686839 & BC ZSM Lep 22366 & Germany \\
\hline Nola cristatula & GWORL465-09 & GU686840 & BC ZSM Lep 22367 & Germany \\
\hline Nola cristatula & GWOTS579-17 & & BC ZSM Lep 94635 & Germany \\
\hline Nola cucullatella & ABOLB410-15 & & KLM Lep 02595 & Austria \\
\hline Nola cucullatella & CGUKA296-09 & KX043052 & UKLB4B03 & United Kingdom \\
\hline Nola cucullatella & CGUKB131-09 & MF102756 & UKLB13A02 & United Kingdom \\
\hline Nola cucullatella & CGUKB135-09 & MF102445 & UKLB13A06 & United Kingdom \\
\hline Nola cucullatella & CGUKC005-09 & MF102776 & UKLB22C07 & United Kingdom \\
\hline Nola cucullatella & CGUKD503-09 & KX044188 & UKLB38C01 & United Kingdom \\
\hline Nola cucullatella & FBLMU514-09 & HM391843 & BC ZSM Lep 27164 & Germany \\
\hline Nola cucullatella & FBLMU515-09 & HМ391844 & BC ZSM Lep 27165 & Germany \\
\hline Nola cucullatella & GBLAB621-13 & MF102573 & BC ZSM Lep 75392 & Germany \\
\hline Nola cucullatella & GBLAD420-14 & MF102502 & BC ZSM Lep 77946 & Germany \\
\hline Nola cucullatella & GWOR4216-09 & JF415818 & BC ZSM Lep 21500 & Germany \\
\hline Nola cucullatella & GWOTD196-12 & KX041077 & BC ZSM Lep 48412 & Germany \\
\hline Nola cucullatella & GWOTL132-13 & MF102763 & BC ZSM Lep 67063 & Germany \\
\hline Nola cucullatella & IBLAO574-12 & MF102442 & AOC Lep 00669 & Spain \\
\hline Nola cucullatella & IBLAO739-12 & MF102562 & AOC Lep 00834 & Spain \\
\hline Nola cucullatella & LEFIC237-10 & HM872081 & MM03640 & Finland \\
\hline Nola cucullatella & LEFIC788-10 & HM872607 & MM04925 & Finland \\
\hline Nola cucullatella & LEFIE701-10 & HM874422 & MM09683 & Finland \\
\hline Nola cucullatella & LENOA1192-11 & KX044672 & LN-BD0715 & France \\
\hline Nola cucullatella & LON4206-16 & & NHMO-DAR-10150 & Norway \\
\hline Nola cucullatella & LON452-08 & KX048888 & NHMO-08102 & Norway \\
\hline Nola cucullatella & NLLEA585-12 & KX049047 & RMNH.INS.540777 & Netherlands \\
\hline Nola cucullatella & PHLAE252-11 & JN284313 & TLMF Lep 04472 & Austria \\
\hline Nola cucullatella & RDNMD724-06 & MF102744 & CNCNoctuoidea 13056 & Denmark \\
\hline Nola cucullatella & RDNMD746-06 & MF102644 & CNCNoctuoidea 13078 & Denmark \\
\hline Nola cucullatella & ABOLB717-15 & & KLM Lep 03377 & Austria \\
\hline Nola cucullatella & CGUKB555-09 & MF102488 & UKLB17E04 & United Kingdom \\
\hline Nola cucullatella & CGUKC424-09 & MF102752 & UKLB26G02 & United Kingdom \\
\hline Nola cucullatella & CGUKD373-09 & KX043083 & UKLB36H01 & United Kingdom \\
\hline Nola cucullatella & GWOTL131-13 & MF102701 & BC ZSM Lep 67062 & Germany \\
\hline Nola cucullatella & LEATB524-13 & MF102661 & TLMF Lep 10701 & Austria \\
\hline Nola cucullatella & NOENO502-17 & & BC_LSNOE_Lep_00502 & Austria \\
\hline Nola dresnayi & GWOTD193-12 & KX041014 & BC ZSM Lep 48409 & France \\
\hline Nola dresnayi & GWOTD215-12 & KX040047 & BC ZSM Lep 48431 & France \\
\hline Nola estonica & NOLAE015-21 & OL539570 & EÕ1484 & Estonia \\
\hline
\end{tabular}


TABLE 1. (Continued)

\begin{tabular}{|c|c|c|c|c|}
\hline Species & BOLD & GenBank & Sample ID & Country \\
\hline Nola estonica & NOLAE016-21 & OL539571 & EÕ1488 & Estonia \\
\hline Nola estonica & NOLAE017-21 & OL539572 & EÕ1489 & Estonia \\
\hline Nola estonica & NOLAE018-21 & OL539573 & EÕ1490 & Estonia \\
\hline Nola estonica & NOLAE019-21 & OL539574 & EÕ1529 & Estonia \\
\hline Nola estonica & NOLAE020-21 & OL539575 & EÕ1550 & Estonia \\
\hline Nola estonica & NOLAE021-21 & OL539576 & EÕ1552 & Estonia \\
\hline Nola estonica & NOLAE022-21 & OL539577 & TUZ300207 & Estonia \\
\hline Nola estonica & NOLAE023-21 & OL539578 & TUZ300208 & Estonia \\
\hline Nola estonica & NOLAE024-21 & OL539579 & TUZ300209 & Estonia \\
\hline Nola estonica & NOLAE025-21 & OL539580 & TUZ300210 & Estonia \\
\hline Nola estonica & NOLAE026-21 & OL539581 & TUZ300211 & Estonia \\
\hline Nola estonica & NOLAE027-21 & OL539582 & TUZ300212 & Estonia \\
\hline Nola estonica & NOLAE028-21 & OL539583 & TUZ300213 & Estonia \\
\hline Nola estonica & NOLAE029-21 & OL539584 & TUZ300214 & Estonia \\
\hline Nola estonica & NOLAE030-21 & OL539585 & TUZ300215 & Estonia \\
\hline Nola estonica & NOLAE031-21 & OL539586 & TUZ300255 & Estonia \\
\hline Nola estonica & NOLAE032-21 & OL539587 & TUZ300256 & Estonia \\
\hline Nola estonica & NOLAE033-21 & OL539588 & TUZ300257 & Estonia \\
\hline Nola estonica & NOLAE034-21 & OL539589 & TUZ300285 & Estonia \\
\hline Nola estonica & NOLAE035-21 & OL539590 & TUZ300286 & Estonia \\
\hline Nola estonica & NOLAE036-21 & OL539591 & TUZ300298 & Estonia \\
\hline Nola estonica & NOLAE037-21 & OL539592 & TUZ300299 & Estonia \\
\hline Nola estonica & NOLAE038-21 & OL539593 & TUZ300300 & Estonia \\
\hline Nola estonica & NOLAE039-21 & OL539594 & TUZ300301 & Estonia \\
\hline Nola estonica & NOLAE040-21 & OL539595 & TUZ300309 & Estonia \\
\hline Nola estonica & NOLAE041-21 & OL539596 & MNU NE1 & South Korea \\
\hline Nola estonica & NOLAE042-21 & OL539597 & MNU NE7 & South Korea \\
\hline Nola estonica & NOLAE043-21 & OL539598 & MNU NE8 & South Korea \\
\hline Nola estonica & NOLAE044-21 & OL539599 & MNU NE10 & South Korea \\
\hline Nola fraterna & MAMTJ917-12 & KX862465 & BIOUG02380-D07 & Pakistan \\
\hline Nola fraterna & GMPBK2144-18 & & BIOUG40824-A02 & Pakistan \\
\hline Nola fraterna & GMPBK2154-18 & & BIOUG40824-A12 & Pakistan \\
\hline Nola fraterna & GMPBK2215-18 & & BIOUG40824-G01 & Pakistan \\
\hline Nola fraterna & GMPBY012-18 & & BIOUG41154-F06 & Pakistan \\
\hline Nola fraterna & GMPBZ006-18 & & BIOUG41266-C10 & Pakistan \\
\hline Nola fraterna & GMPBZ027-18 & & BIOUG41266-E07 & Pakistan \\
\hline Nola karelica & GWOTD209-12 & KX040278 & BC ZSM Lep 48425 & Finland \\
\hline Nola karelica & LEFIF276-10 & HM874969 & MM11058 & Finland \\
\hline Nola karelica & LEFIF275-10 & HM874968 & MM11057 & Finland \\
\hline Nola karelica & LEFIF277-10 & HM874970 & MM11059 & Finland \\
\hline Nola karelica & LEFIG991-10 & HQ570421 & MM15855 & Finland \\
\hline Nola karelica & LON918-12 & KX047688 & RV090 & Norway \\
\hline Nola squalida & GWOTD199-12 & KX040254 & BC ZSM Lep 48415 & Spain \\
\hline
\end{tabular}


TABLE 1. (Continued)

\begin{tabular}{lllll}
\hline Species & BOLD & GenBank & Sample ID & Country \\
\hline Nola subchlamydula & FBLMW301-10 & HQ563546 & BC ZSM Lep 37402 & Germany \\
Nola subchlamydula & GWOSF580-10 & KX040184 & BC ZSM Lep 41576 & Spain \\
Nola subchlamydula & LEATD009-13 & & TLMF Lep 12656 & Italy \\
Nola subchlamydula & LEATD010-13 & & TLMF Lep 12657 & Italy \\
Nola subchlamydula & LEATJ095-15 & & TLMF Lep 18525 & Italy \\
Nola subchlamydula & LON7216-18 & & KBE 2018482 & Croatia \\
Nola subchlamydula & LON7217-18 & & KBE 2018483 & Croatia \\
Nola subchlamydula & PHLAF585-11 & & TLMF Lep 05755 & Italy \\
Nola subchlamydula & PHLAG082-12 & KX046876 & KLM Lep 00272 & Italy \\
Nola thymula & GWOTD203-12 & KX040180 & BC ZSM Lep 48419 & Spain \\
\hline
\end{tabular}

\section{Results}

\section{Morphological study}

Analysis of the external and genitalic characters of $N$. aerugula aerugula, $N$. aerugula atomosa and the third, unknown taxon revealed that there are constant differences suggesting these taxa to be separate species. Below, we describe the unknown taxon as Nola estonica Õunap sp. nov. and reinstate Glaphyra atomosa Bremer, 1861 from a subspecies of Nola aerugula (Hübner, 1793) to species level as Nola atomosa (Bremer, 1861) stat. rev.

\section{Nola estonica Õunap sp. nov.}

(Figures 1-18, 43-44, 49-51, 55)

\section{Type material}

Holotype: + , Estonia, Piusa Railway Station, at light, 5750’20.9’N 2728'15.0”E, 03.08.2020, leg. E. Õunap, TUZ300299 .

Paratypes, $82 \hat{\jmath} \hat{0}, 53$ 웅.

\section{EsTONIA}

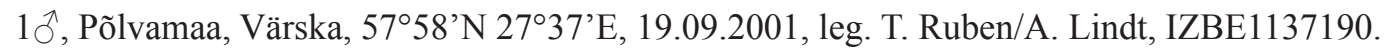

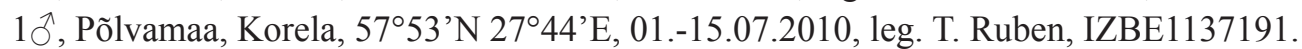

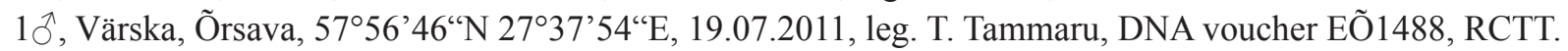

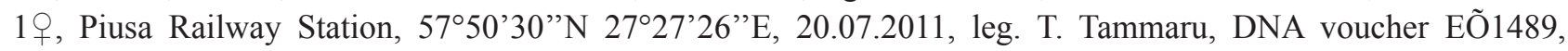
RCTT.

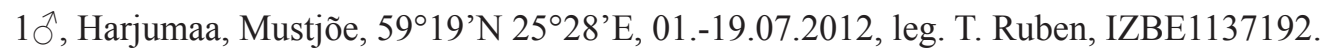

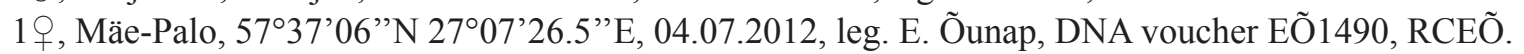

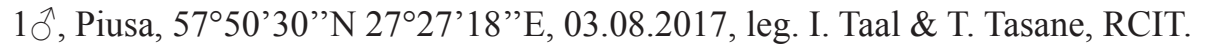

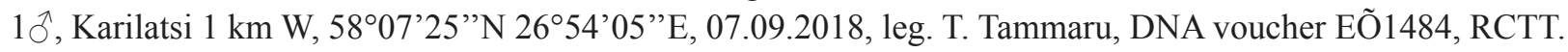

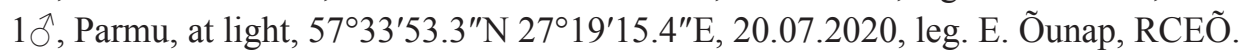

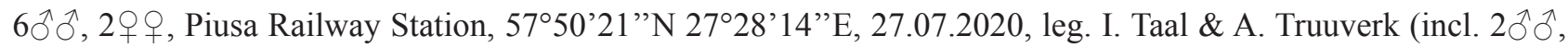
DNA vouchers EÕ1550, EÕ1552, used for genetic study), RCIT.

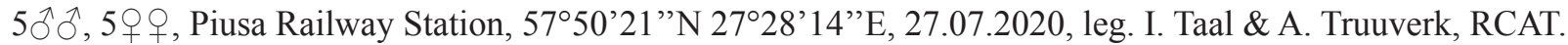

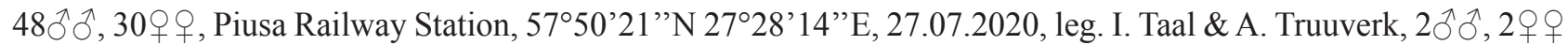
dissected, TUZ300207-TUZ300284.

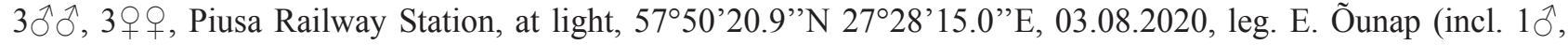
DNA voucher EÕ1529, used for genetic study) RCEÕ.

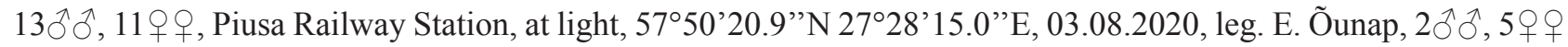
dissected, TUZ300285-TUZ300298, TUZ300300-TUZ300309 . 


\section{Other material examined}

Russia

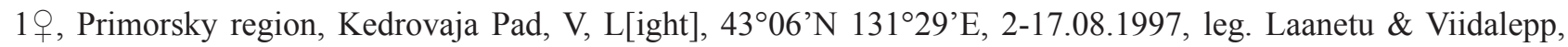
dissected, IZBE0106558.

10, Amurskaja region, Svobodnenski district, Iverskii zakaznik, 18.06.-01.07.2010, leg. A. Barbarich, A. Streltsov, P. Osipov, dissected, slide Matov 0589, ZISP.

SOUTH Korea

6우, Mt. Samaksan, Deokduwon-ri, Seo-myon, Chuncheon, Gangwon-do Province, at light, 3750'11"N 127³7’30”'E, 25.06.2016, leg. S. S. Kim, 2 qq dissected, MNU genital slides no. 1172 and 1173, MNU 5MNU 10.

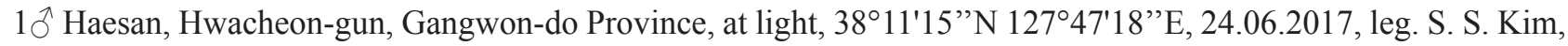
dissected, MNU genital slide no. 1170, MNU NE1.

\section{Description}

External morphology. Wingspan 15.2-18.1 (average 16.4 $\pm 1.0 \mathrm{SD}, \mathrm{n}=18$ ) $\mathrm{mm}$ in males 15.4-19.0 (average 17.2 \pm 1.0 SD, $\mathrm{n}=16) \mathrm{mm}$ in females. Head white, antennae covered with white scales. Male antennae bipectinate, bearing numerous sensilla on the ventral side. The length of sensilla exceed the diameter of the flagellum. Female antennae filiform. Labial palpi porrect, elongated, more than two times longer than the diameter of the eye, intermixed with light and dark scales on the lateral side, but only white scales present on the medial side. Proboscis present. Thorax white. Forewing elongated, apex rounded. Upperside white. Three tufts of raised scales present along the anterior edge of the cell, the medial and distal tuft always containing at least some dark scales, the proximal tuft sometimes completely white. Subbasal line present as a brown costal blotch, sometimes completely absent. Antemedial line, if present, usually brown, rarely black, jagged, forming an irregular curve towards the termen. A large brown blotch sometimes present on costa proximal to the antemedial line. Medial line absent. Postmedial line brown, rarely black, parallel to costa in the subcostal region, but turns towards inner margin at an acute angle on $\mathrm{R}_{5}$. Postmedial line almost straight between $R_{5}$ and inner margin, with clear darker spots on veins, sometimes proximally accompanied by a light brown band. Subterminal line undulating, light brown to light grey, sometimes completely absent. Terminal line light brown to light grey, sometimes hardly visible, sometimes interrupted by a row of white or yellowish dots on veins. Fringes usually unicolourous, white, light beige or light grey, rarely slightly lighter on veins. Pattern reduced in many specimens, sometimes represented only by a few dark scales on subcostal hair tufts, and as a row of small dark dots referring to postmedial line. Underside unicolourous dark grey in males, white with most veins dark grey and some grey scales diffused between the veins in females. Hindwing with evenly curved termen, apex rounded. Upperside white, subcostal region light grey. In darker specimens wings gradually darkening from white to light grey in subterminal area. Discal spot very weak, formed by a small number of dark scales. Terminal line light grey, interrupted by a row of white or yellowish dots on veins, sometimes hardly visible. Fringes white, light beige or light grey. Underside white, with diffused grey scales mostly present on the anterior half of the wing and on the subterminal area. Discal spot grey. Legs white or grey, darker in males than in females, one pair of tibial spurs present in midlegs, and two pairs in hindlegs of both sexes. Abdomen dorsally light yellowish grey, posterior edges of segments visible as a row of lighter scales. Ventral side of the abdomen light yellowish grey suffused with small number of black scales.

Male genitalia. Uncus absent. Tegumen narrow, 1.5 times longer than vinculum. Saccus short and very wide, with rounded tip. Scaphium with two extremely long, parallel, stick-like, sclerotized structures. Valva long, bilobed, costa and ventral margin heavily sclerotized, rounded at both tips. Tip of the ventral lobe of valva extended to a tiny hook. Harpe strong, triangular, spine-like, with a pointed tip. Editum present as a rounded protuberance bearing a number of tiny papilles carrying thin setae, positioned close to base of costa. Transtilla narrow, heavily sclerotized. Juxta plate-like, laterally extended as two arms to dorsal side. Aedeagus almost straight, three times longer than wide, apex ventrally elongated as a thin triangular slat, coecum absent. Vesica straight, slightly wider and longer than aedeagus, with one cornutus. Cornutus short and wide, with a prominent central ridge extending beyond its posterior edge. Eighth tergite with two narrow anterior projections located wide apart from each other, posterior edge of the heavily sclerotized area rounded. 
Female genitalia. Ovipositor short, very wide; posterior apophyses approximately as long as ovipositor. Anterior apophyses short, their length approximately $2 / 3$ of the length of posterior apophyses. Ostium bursae heavily sclerotized, genital orifice oval, wider than long. Antrum region very short, membranous. Posterior part of ductus bursae moderately sclerotized, the sclerotized region wider than long, its length about $1 / 5$ of the total length of ductus bursae. Middle part of ductus bursae membranous, two times longer than wide, the membrane slightly wrinkled, sometimes with irregular patches of sclerotization. Anterior part of ductus bursae heavily sclerotized, dilated, sclerotization present as irregular longitudinal folds. Corpus bursae ovoid, elongate, 2.5 times longer than wide, with one signum. The posterior part of signum bursae bearing a heavily sclerotized thorn pointing towards the lumen of corpus bursae.

Diagnosis. $N$. estonica (Figures 1-18) differs from N. atomosa by its rather straight postmedial line which is darker on veins and often divided into a row of dark spots. The postmedial line of N. atomosa (Figures 19-30) is strongly undulating and almost unicolourous. Even in very light specimens of $N$. atomosa the postmedial line is not interrupted into separate spots located on veins. In $N$. atomosa, fringes are chequered, being white on tips of the veins, and light grey between the veins. Male genitalia of $N$. estonica (Figures 43ab, 44ab) and N. atomosa (Figures $45 \mathrm{ab}, 46 \mathrm{ab})$ are very similar and cannot be used for reliable identification. However, the 8th tergite of N. estonica has narrow anterior projections that are situated apart from each other (Figures 43c, 44c), while that of $N$. atomosa usually has wide anterior projections that are located much closer to each other (Figures 45c, 46c). Females of $N$. estonica can easily be separated from $N$. atomosa by genitalia dissection, as this species has only one signum in bursa copulatrix, which is located ventrolaterally (Figures 49-51). N. atomosa has an additional smaller signum on the opposite side of bursa copulatrix (Figures 52-53), though the latter may be small, almost transparent and therefore hard to notice. A fine detail characteristic of $N$. estonica is an inward-pointing thorn on the posterior edge of signum (Figure 55). Though the posterior edge of the larger signum of $N$. atomosa is also bent inwards (Figure 56 ), it does not form a distinct narrow thorn. The sclerotized posterior part of ductus bursae is wider than long in $N$. estonica, but almost rectangular in $N$. atomosa.

$N$. aerugula (Figures 31-42) can usually be separated from $N$. estonica by its much darker colouration. Even in very light specimens of $N$. aerugula the ground colour of forewings is often yellowish, not white, as opposed to the pure white ground colour of $N$. estonica. Though the postmedial line of $N$. aerugula is sometimes almost as straight as that of $N$. estonica, it is not distinctly darker on veins nor divided into a row of spots. The hindwings of $N$. aerugula are almost unicolourous and darker than those of $N$. estonica: dark grey in the darkest specimens, light grey in the lightest ones. Male genitalia of $N$. aerugula (Figures 47a, 48a) differ from those of $N$. estonica (Figures 43a, 44a) by shorter vinculum, which has length/width ratio of about 0.5 (as opposed to at least 0.6 in $N$. estonica), and by very short and narrow saccus. There are, however, no differences in the shape of the aedeagus of $N$. estonica (Figures 43b, 44b) and $N$. aerugula (Figures 47b, 48b). The 8th tergite of $N$. estonica has narrow anterior projections that are situated apart from each other (Figures $43 \mathrm{c}, 44 \mathrm{c}$ ), while that of $N$. aerugula usually has wide anterior projections that are located much closer to each other (Figures 47c, 48c). Females of $N$. estonica can easily be separated from $N$. aerugula by genitalia dissection, as this species has only one ventrolateral signum on bursa copulatrix (Figures 49-51), but $N$. aerugula has an additional smaller signum on the opposite side of bursa copulatrix (Figure 54). However, the latter may be small, almost transparent and therefore hard to notice. The larger signum of $N$. aerugula is often just a flat patch of sclerotization on the wall of bursa copulatrix which is thicker on its posterior edge (Figure 57), but sometimes its posterior edge is bent inwards. Even in the latter case it does not form a distinct narrow inward-pointing thorn which is characteristic to $N$. estonica. The sclerotized posterior part of ductus bursae is wider than long in N. estonica, but almost rectangular in N. aerugula.

Note. Though the hitherto known European and Far Eastern populations of N. estonica are separated by at least 6000 kilometers, we have not found any consistent differences in their morphology. The South Korean and Russian specimens fit well within the intraspecific variation of the Estonian material.

Biology. N. estonica appears to be locally common in southeastern Estonia. The majority of the type series were collected from a dry, narrow meadow stripe in the railway corridor that penetrates a landscape dominated by dry pine forest on sandy soil. Whether the species prefers woodland or open habitat is yet unknown, as though the moths were captured on a meadow, they may have flown to light from the nearby forest only 15-20 meters away. In South Korea, the moths were collected in mountainous woodland with mixed coniferous and deciduous trees, and the single contemporary specimen from Russian Far East was taken from mixed forest adjacent to large xerophytic meadows. Most of the hitherto known specimens have been collected in July and early August, but two records from 
September suggest that partial second brood may exist. Other details of the life cycle and larval foodplants are not known.

Etymology. The name estonica refers to Estonia, as the species was first discovered in this country, which is also the area of origin of the type series.

\section{Nola atomosa (Bremer, 1861) stat. rev.}

(Figures 19-30, 45-46, 52-53, 56)

Glaphyra atomosa Bremer, 1861, Bulletin de l'Académie Impériale des sciences de St-Petersbourg 3: 491. LT: Amur, Russian Federation

= Nola candidalis Staudinger, 1892, Mémoires sur les Lépidoptères 6: 258. TL: Amur, Russian Federation syn. nov.

= Nola shin Inoue, 1982, Moths of Japan: 661. TL: Shibecha, Kushiro, Hokkaido, Japan syn. nov.

\section{Type material examined.}

Lectotype of Glaphyra atomosa Bremer, 1861, hereby designated: Ô, RussiA, dark brown label „Ussuri“, „Maack“, white label „coll. Acad. Petrop.“, red label „Glaphyra atomosa Bremer, 1861, LECTOTYPE, des. Matov \& Õunap 2021“, white label „slide Matov 0588“, ZISP.

Paralectotypes, hereby designated: $1 \hat{0}$, 1 \% , RussiA, dark brown label „Ussuri“, „Maack“, white label „,coll. Acad. Petrop.“, red label „Glaphyra atomosa Bremer, 1861, PARALECTOTYPE, des. Matov \& Õunap 2021, ZISP.

\section{Other material examined}

NORTH KOREA

1ठ, [North] Korea, 20/6 [20.06.][1903?], leg. Herz, ZISP.

RUSSIA

10ิ, Primorsky region, Ussuriisk (as Nikolsk-Ussuriisk on the label), Baranovskij polygon, 1913, leg. Andrievskii, ZISP.

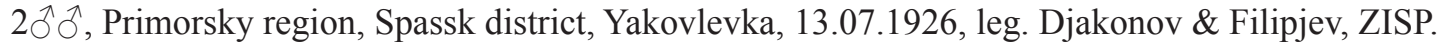

1§̂, Primorsky region, Spassk district, Yakovlevka, 14.07.1926, leg. Djakonov \& Filipjev, dissected, slide Matov 0590, ZISP.

$2 \widehat{\partial^{\lambda}}, 2$ 우우, Primorsky region, Spassk district, Yakovlevka, 17.07.1926, leg. Djakonov \& Filipjev, ZISP.

1§ึ, 2 우우, Primorsky region, Spassk district, Yakovlevka, 23.07.1926, leg. Djakonov \& Filipjev, ZISP.

19, Primorsky region, Spassk district, Yakovlevka, 29.07.1926, leg. Djakonov \& Filipjev, ZISP.

$1{ }^{\lambda}$, Primorsky region, Suchan, 26.07.1928, leg. Kurentsov, ZISP.

1오, Primorsky region, Suchan, 27.07.1928, leg. Kurentsov, ZISP.

$5 \hat{\jmath} \widehat{\partial}$, Primorsky region, Vinogradovka, 19.-20.07.1929, leg. Djakonov \& Filipjev, 1 ô dissected, slide Matov 0592, ZISP.

1옹 Primorsky region, vic. Vladivostok, Chernaya Rechka, 02.08.1931, leg. Moltrecht, ZISP.

$1{ }^{\top}$, Primorsky region, Suchansk, rudnik, 16.08.1933, leg. Palshikov, dissected, slide Matov 0591, ZISP.

$1{ }^{\Uparrow}$, Primorsky region, Khasan, at light, 14.07.1959, leg. A. Zemlina, ZISP.

1 , , Primorsky region, Ugolnaja Ussuri region, 31.07.1960, leg. L. Anufriev, ZISP.

1 , , Primorsky region, Kaimanovka, 23.07.1961, leg. A. Ivanov, ZISP.

$1 \widehat{\jmath}, 2$ 우우, Khabarovsk, leg. Graeser, ex coll. Dieckmann, 1 ○ dissected, slide Matov 0593, ZISP.

1今ึ, Khabarovsk, L[ight], 07.07.1973, leg. Viidalepp, Kullman, Tiivel, IZBE0106553.

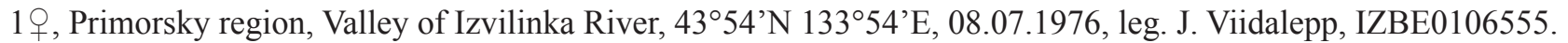

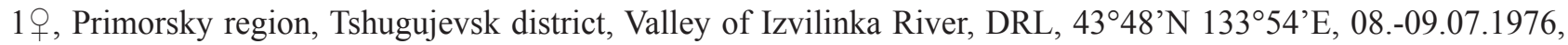
leg. Metsaviir, Viidalepp, dissected, slide J. Viidalepp 2402, IZBE0106556.

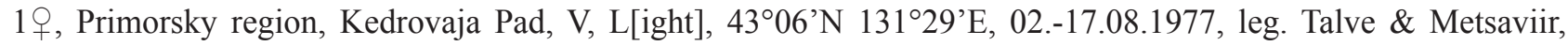
dissected, IZBE0106557.

10, Khabarovsk region, Nelma, $47^{\circ} 40^{\prime} \mathrm{N} 139^{\circ} 10^{\prime} \mathrm{E}, 16 .-26.07 .1977$, leg. Viidalepp, Laanetu, Talve, IZBE0106554.

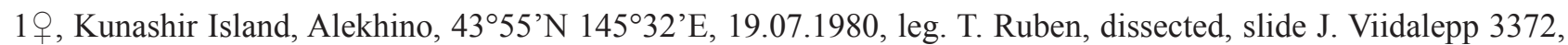
IZBE0106559. 
1§̂, Amur region, Svobodnenski district, Iverskii zakaznik, 18.06.-01.07.2010, leg. A. Barbarich, A. Streltsov, P. Osipov, ZISP.

\section{SOUTH KoreA}

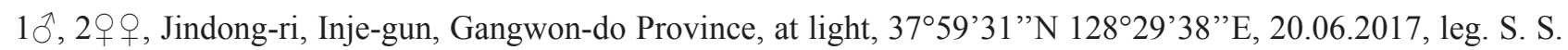

Kim, 1 q dissected, MNU genital slide no. 1171, MNU 2-MNU 4.

Diagnosis. Wingspan 15-19 mm. N. atomosa (Figures 19-30) is best characterized by the heavily undulating postmedial line and chequered fringes of the forewing, though the most light-coloured specimens (Figure 30) can be almost without any pattern. Further morphological details allowing to distinguish it from N. estonica have been discussed above. $N$. aerugula (Figures 31-42) has a straighter postmedial line than $N$. atomosa, and the fringes of its forewings are almost always completely unicolourous. The hindwing of $N$. atomosa is light, unicolourous or gradually darkening in subterminal area, but never completely dark as that of many specimens of $N$. aerugula. Male $N$. aerugula (Figures 47a, 48a) can be separated by its shorter vinculum and saccus but the shape of aedeagus and 8th tergite of this species (Figures $47 \mathrm{bc}, 48 \mathrm{bc}$ ) are similar to those of $N$. atomosa (Figures $45 \mathrm{bc}, 46 \mathrm{bc}$ ). Females of both $N$. atomosa (Figures 52,53) and $N$. aerugula (Figure 54) have two signa in the opposite sides of bursa copulatrix. The shape of the larger (ventrolateral) signum, however, is variable. In $N$. atomosa the posterior edge of the larger signum bends inwards towards the lumen of bursa copulatrix (Figure 56), though it does not form as distinct thorn as in $N$. estonica. In many specimens of $N$. aerugula both signa are just flat patches of sclerotization on the bursa wall, though the larger one is somewhat thickened on its posterior edge (Figure 57). However, we have also observed that in some specimens of $N$. aerugula the posterior edge of the larger signum is also bent inwards. Therefore the shape of the signum alone should not be used to distinguish this species from N. atomosa.

Note. $N$. atomosa has been considered to be an eastern subspecies of N. aerugula (Oh 2001, Matov 2019). Consequently, additional eastern Palaearctic taxa Nola candidalis Staudinger, 1892 and Nola shin Inoue, 1982 which are conspecific with $N$. atomosa, have been treated earlier as synonyms of $N$. aerugula (e. g. Oh 2001, Fibiger et al. 2009, Sasaki 2011, Hacker et al. 2012). As N. atomosa is reinstated as a valid species in this article, neither $N$. candidalis or $N$. shin can no longer be treated as synonyms of $N$. aerugula. Therefore, we hereby establish the priority of $N$. atomosa over junior synonyms as follows: Nola atomosa $($ Bremer, 1861) $=$ Nola candidalis Staudinger, 1892 syn. nov. and Nola shin Inoue, 1982 syn. nov.

\section{Nola aerugula (Hübner, [1793])}

(Figures 31-42, 47-48, 54, 57)

Phalaena Bombyx aerugula Hübner, [1793], Sammlung Auserlesener Vögel und Schmetterlinge, mit ihrem Namen Herausgegeben auf Hundert nach der Natur Ausgemalten Kupfern: 11, pl. 61. LT: [Europe]

= Pyralis centonalis Hübner, 1796, Sammlung Europäischer Schmetterlinge 6: pl. 3, fig. 15. LT: [Europe]

= Hercyna scabralis Eversmann, 1842, Bulletin de la Société Impériale des Naturalistes de Moscou, 15: 562. LT: Russia

= Nola littoralis Paux, 1901, Bulletin scientifique de la France et de la Belgique 35: 479. LT: Dunkerque, France

\section{Type material examined}

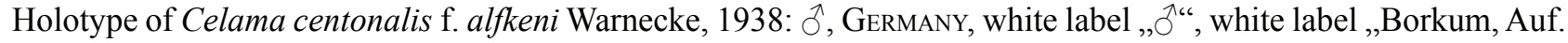
VII. 1924, am licht“, red label „n. f. Alfkeni, Warnecke, Type“, white label „photographiert, Warnecke 1933“, white label „Slg-G Warnecke, Eing Nr 5 1949“, white label „ZMH 833303“, ZMH.

Paratypes of Celama centonalis f. alfkeni Warnecke, 1938: §̊, GermanY, white label „26.8.35, St.“, white label „Insel Borkum, 1935 Struve“, red label „f. Alfkeni Warn., Paratype“, white label „Sammlung, G. Warnecke, Eing. Nr. 5, 1949“, white label „Slg-G Warnecke, Eing Nr 5, 1949“, white label „ZMH 833304“, ZMH; Oૈ, GermanY, white label „7.7.34, Bl“, white label „Ins. Borkum, 1935 Struve“, red label „f. Alfkeni Warn., Paratype“, white label „Sammlung, G. Warnecke, Eing. Nr. 5, 1949“ white label „ZMH 833305“, ZMH.

Lectotype of Hercyna scabralis Eversmann, 1842: + , Russia, white label „Simb.” [Simbirsk], white label “coll. Eversmann", red label "LECTOTYPUS + , Hercyna scabralis, Eversmann, 1942, design. S. Yu. Sinev, 2015”, ZISP.

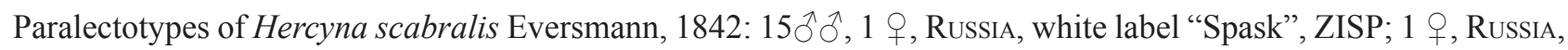


white label "Orb" [Orenburg], ZISP; 1 ô, RusSIA, white label "Kas" [Kazan], ZISP; 1 ô, RuSSIA, white label "Menzelinsk", ZISP; 1 §, 1 +, no label with geographic name, ZISP.

\section{Other material examined}

EsTONIA

19, 19.06.1881, leg. F. Sintenis, IZBE1136185.

1ㅇ, sph. Sonda, 03.07.1937, leg. D. Kuskov, dissected, IZBE1136200.

$10^{\top}$, Kohala, $59^{\circ} 25^{\prime} \mathrm{N} 26^{\circ} 32^{\prime} \mathrm{E}, 13.07 .1991$, leg. E. Mäe, TUZ407496.

1우, Teenuse, $58^{\circ} 48^{\prime} 52.2^{\prime}{ }^{\prime} \mathrm{N} 24^{\circ} 11^{\prime} 23.3^{\prime \prime} \mathrm{E}, \mathrm{L}$ [ight], 12.07.1992, leg. R. Ülemaante, dissected, IZBE1136225.

$10^{\top}$, Kohala, 59²5’N 26³2'E, 18.07.1992, leg. E. Mäe, TUZ407489.

$10^{\Uparrow}$, Kohala, $59^{\circ} 25^{\prime} \mathrm{N} 26^{\circ} 32^{\prime}$ E, 23.07.1992, leg. E. Mäe, TUZ407494.

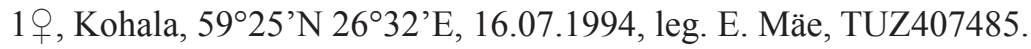

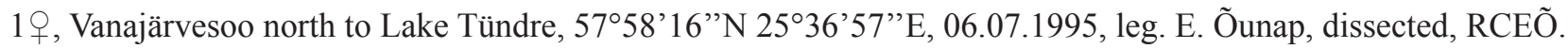

$1 \hat{\delta}$, Verhulitsa, at light, 14.07.2003, leg. E. Õunap, RCEÕ.

1 , , Verhulitsa, at light, 21.07.2004, leg. E. Õunap, RCEÕ.

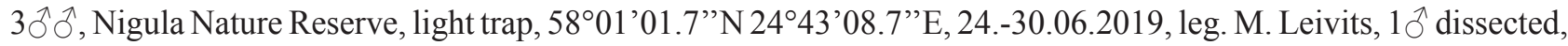
IZBE1137193-IZBE1137195.

10, Piilse, light trap, 59¹4'10.5”N 2659’49.2”E, 14.-20.07.2019, leg. A. Täpsi, dissected, IZBE1137196.

10, Nigula Nature Reserve, light trap, $58^{\circ} 01^{\prime} 01.7^{\prime \prime} \mathrm{N} 24^{\circ} 43^{\prime} 08.7^{\prime \prime} \mathrm{E}, 22 .-28.06 .2020$, leg. M. Leivits, dissected, IZBE1137197.

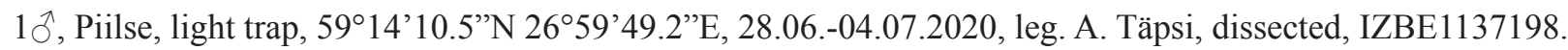

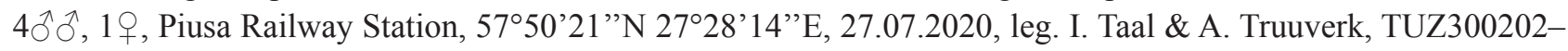
TUZ300206.

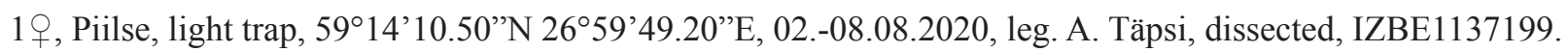

Georgia

10ึ, Georgia, Poti, 06.08.1939, leg. G. Lvov, ZISP.

RUSSIA

1옹 Irkutsk Oblast, 12.07.1916, leg. Markova, ZISP.

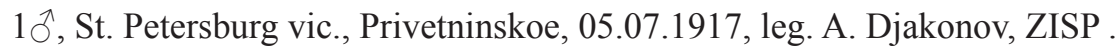

19, St. Petersburg vic., Sablino, 09.07.1922, leg. A. Djakonov, ZISP.

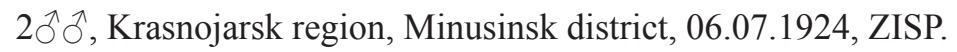

10 , Krasnojarsk region, Minusinsk district, 14.07.1926, ZISP.

10, Krasnojarsk region, Enisejsk, 23.07.1930, leg. Kvetmanov, ZISP.

$1{ }^{\lambda}$, Kemerovo region, Vaganovo, 26.06.1955, leg. Falkovitsh, ZISP.

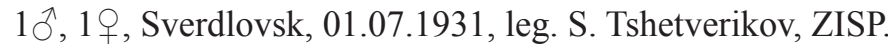

10, Sverdlovsk, 05.07.1931, leg. S. Tshetverikov, ZISP.

1ðึ, Tuva Republic, Kyzyl, Kaa-Hem, L[ight], 08.07.1972, leg. Ruben, Viidalepp, IZBE0106551.

1§, Tuva Republic, Kyzyl, Kaa-Hem, L[ight], 01.08.1972, leg. Ruben, Viidalepp, IZBE0106552.

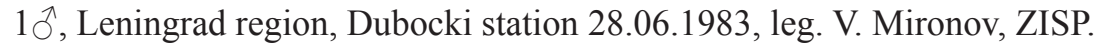

19, Altai region, Zonalnoje, on tree trunk, 20.07.1989, leg. T. Tammaru, RCTT.

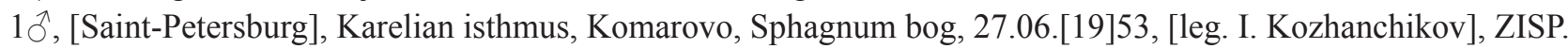

Diagnosis. Wingspan 16-19 mm. In most cases, $N$. aerugula can easily be separated from $N$. estonica and $N$. atomosa by its well expressed dark pattern on the forewings and unicolourous grey hindwings. Further morphological details allowing to distinguish these species have been discussed above.

Note. $N$. aerugula is known for rather extensive variation in the intensity of markings on the wings (de Freina \& Witt 1987, Fibiger et al. 2009), ranging from individuals with almost completely pale yellowish white forewings that have hardly any markings (f. alfkeni Warnecke, 1938) to very dark specimens with entirely brown forewings (f. fumosa Berger, 1918). Interestingly, the lighter forms seem to be dominant in the eastern part of its range, as all Siberian specimens of $N$. aerugula in coll. ZISP are rather light. 


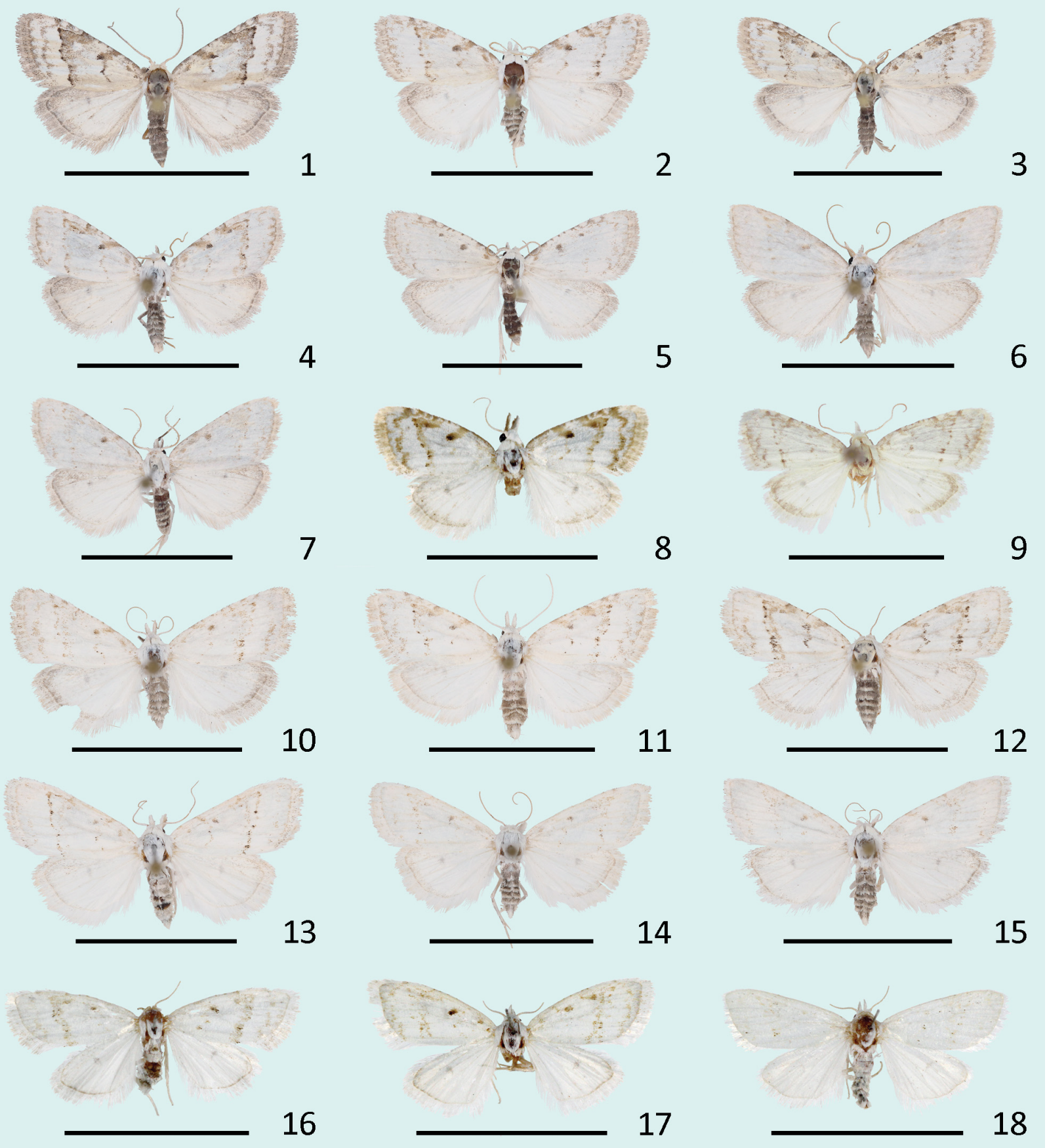

FIGURES 1-18. External habitus of Nola estonica sp. nov. Dorsal view. 1. ð̃, PARATYPE, Estonia, Piusa Railway Station, 27.07.2020, TUZ300207 (barcoded). 2. đ, PARATYPE, Estonia, Piusa Railway Station, 27.07.2020, RCIT (barcoded, sample ID EÕ1550). 3. đ̃, PARATYPE, Estonia, Piusa Railway Station, 27.07.2020, TUZ300208 (barcoded). 4. Õ, PARATYPE, Estonia,

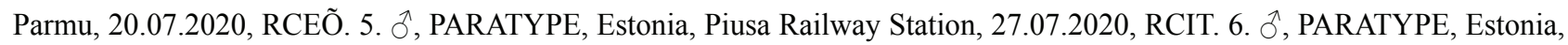
Piusa Railway Station, 03.08.2020, RCEÕ. 7. ô, PARATYPE, Estonia, Piusa Railway Station, 03.08.2020, RCEÕ. 8. §̃, South Korea, Haesan, 26.06.2017, coll MNU (barcoded) 9. §̃, Russia, Ivesrkii zakaznik, 18.06.-01.07.2010, coll. ZISP (dissected). 10. \&, HOLOTYPE, Estonia, Piusa Railway Station, 03.08.2020, TUZ300299, (barcoded, dissected). 11. \&, PARATYPE, Estonia, Mäe-Palo, 04.07.2012, RCEÕ (barcoded, sample ID EÕ1490). 12. ๆ, PARATYPE, Estonia, Piusa Railway Station, 27.07.2020, TUZ300255 (barcoded). 13. PARATYPE, Estonia, Piusa Railway Station, 03.08.2020, TUZ300309, (barcoded) . 14. +, PARATYPE, Estonia, Piusa Railway Station, 03.08.2020, RCEÕ. 15. ๆ, PARATYPE, Piusa Railway Station, 03.08.2020, TUZ300308. Estonia, 16. ๆ, South Korea, Mt. Samaksan, 25.06.2016, coll MNU (barcoded). 17. +, South Korea, Mt. Samaksan, 25.06.2016, coll MNU (barcoded, dissected, MNU genital slide no. 1172). 18. ㅇ, South Korea, Mt. Samaksan, 25.06.2016, coll MNU (barcoded). Scale: $1 \mathrm{~cm}$. 


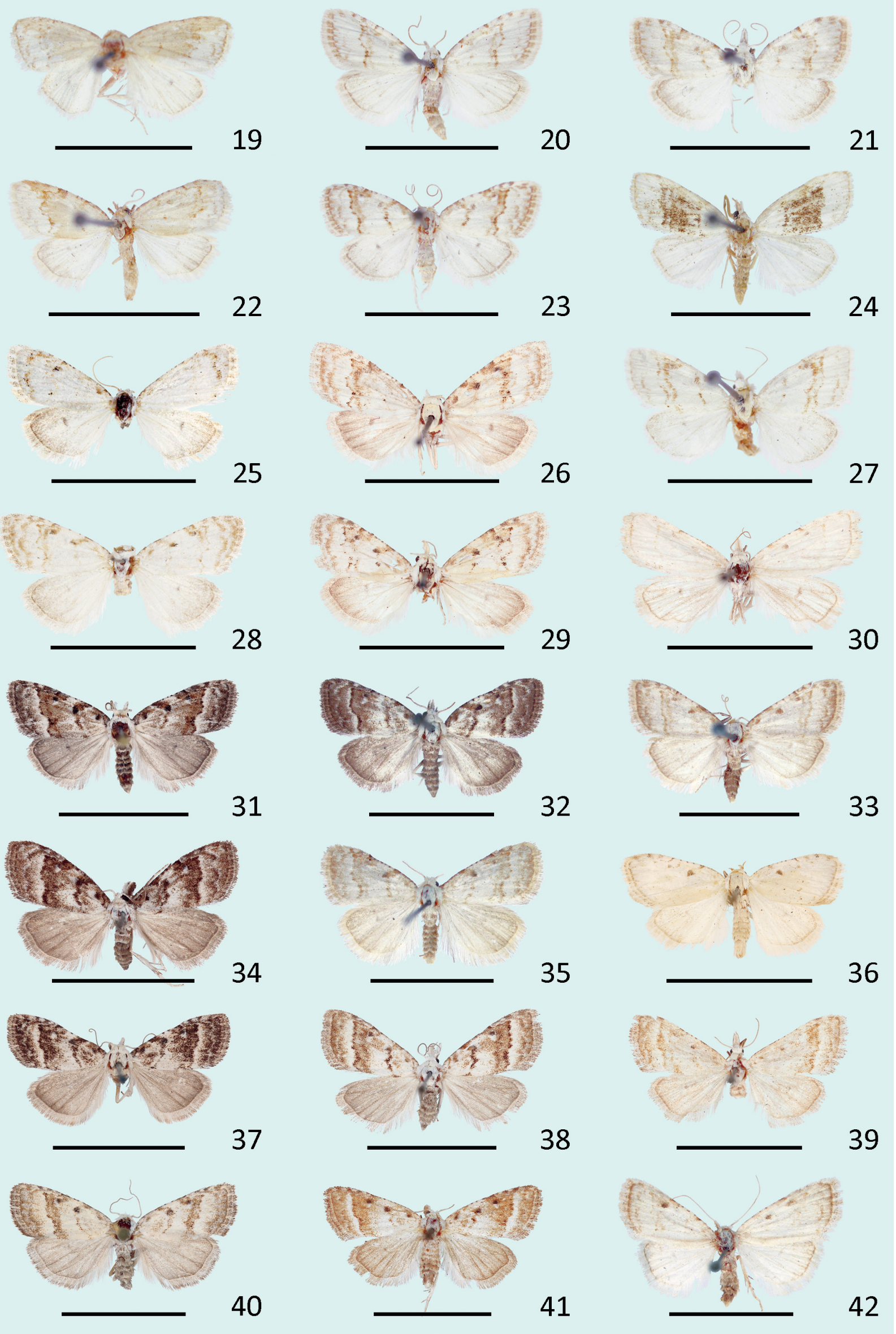


FIGURES 19-42. External habitus of Nola spp. Dorsal view. 19-30. Nola atomosa (Bremer) stat. rev. 31-42. Nola aerugula (Hübner). 19. §, LECTOTYPE of Glaphyra atomosa Bremer, Russia, Ussuri, coll. ZISP (dissected, slide Matov 0588 ). 20. đ̃, Russia, Yakovlevka, 13.07.1926, coll. ZISP. 21. đે, Russia, Yakovlevka, 14.07.1926, coll. ZISP (dissected, slide Matov

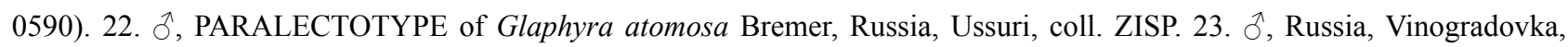

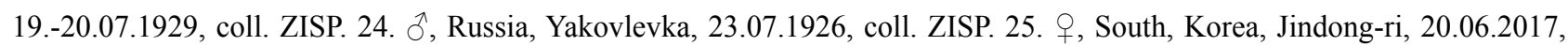
coll. MNU (barcoded, dissected, MNU genital slide no. 1171). 26. \&, Russia, Valley of Izvilinka River, 08.-09.07.1976, IZBE0106556 (dissected, slide J. Viidalepp 2402). 27. q, Russia, Yakovlevka, 29.07.1926, coll. ZISP. 28. + , South, Korea, Jindong-ri, 20.06.2017, coll. MNU (barcoded). 29. \&, \&, Russia, Valley of Izvilinka River, 08.-07.1976, IZBE0106555. 30. , Russia, Alekhino, 19.07.1980, IZBE0106559 (dissected, slide J. Viidalepp 3372). 31. đૈ, Estonia, Nigula Nature Reserve,

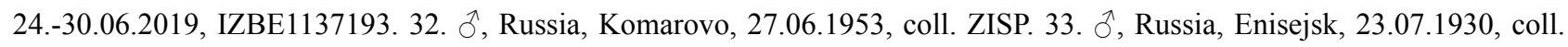

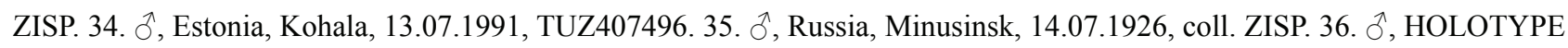
of Celama centonalis f. alfkeni Warnecke, Germany, Borkum, 07.1924, ZMH 833303 (dissected). 37. +, Estonia, Teenuse,

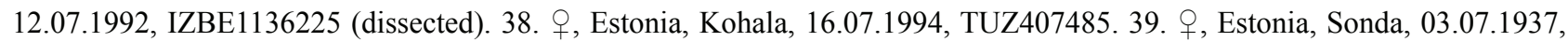
IZBE1136200 (dissected). 40. q, Estonia, Verhulitsa, 21.07.2004, RCEÕ. 41. \&, Estonia, 19.06.1881, IZBE1136185. 42. + (f. alfkeni), Russia, Irkutsk, 12.07.1916, coll. ZISP. Scale: $1 \mathrm{~cm}$.

Sinev et al. (2017) recently demonstrated that the type series of Hercyna scabralis Eversmann, 1824 in coll. ZISP actually is conspecific with $N$. aerugula, as the moths have all characters typical for that species. Therefore, lectotype was designated for $H$. scabralis and illustrated, and this taxon was synonymized with $N$. aerugula (Sinev et al. 2017). Eversmann (1824) had described H. scabralis as a taxon belonging to Pyralidae, which is the likely reason why researchers focusing on Noctuoidea had overlooked this taxon for so long.

\section{DNA barcoding}

All three target species (N. aerugula, N. atomosa, N. estonica) were recovered as monophyletic based on the analysis of DNA barcoding data (Figure 58). Despite being closely related, taken together, they nevertheless do not form an exclusively monophyletic entity, as widespread but morphologically very different Asian species $N$. fraterna (Moore, 1888) appeared as sister taxon to N. estonica, and West European endemic N. dresnayi (Warnecke, 1946) as sister taxon to $N$. aerugula, respectively (Figure 58).

The intraspecific genetic variation varied from 0.000 to 0.011 (average $0.003 \pm 0.002 \mathrm{SD}$ ) in $N$. aerugula, and from 0.000 to 0.012 (average $0.001 \pm 0.003 \mathrm{SD}$ ) in $N$. estonica, whereas the two sequenced specimens of $N$. atomosa differed by just one substitution ( $p$-distance $=0.002$ ). In each interspecific pairwise comparison, the genetic distance exceeded the intraspecific genetic distances presented above at least twice: $0.031-0.04$ (average $0.035 \pm 0.002 \mathrm{SD}$ ) between $N$. aerugula and $N$. atomosa, $0.037-0.055$ (average $0.042 \pm 0.003 \mathrm{SD}$ ) between $N$. aerugula and $N$. estonica, and $0.02-0.028$ (average $0.022 \pm 0.002 \mathrm{SD}$ ) between $N$. atomosa and $N$. estonica.

Further analysis of the data matrix demonstrated that these differences are comparable or even exceed the interspecific genetic distances between our target group and several other Nola species. For example, the genetic distance between $N$. dresnayi and $N$. aerugula $(0.031-0.036$, average $0.034 \pm 0.01)$ is almost identical to that between $N$. aerugula and $N$. atomosa. Moreover, $N$. dresnayi is the species closest to $N$. atomosa judging on barcode data only (p-distance $0.019-0.02$, average $0.02 \pm 0.001$ ). A similar pattern is seen in $N$. estonica, as the results of pairwise interspecific comparisons reveal both $N$. dresnayi (p-distance $0.028-0.033$, average $0.028 \pm 0.001 \mathrm{SD}$ ) and $N$. fraterna (p-distance $0.028-0.033$, average $0.029 \pm 0.001 \mathrm{SD}$ ) to be genetically closer to it than is $N$. aerugula. We therefore conclude that treating all three taxa considered in the present paper ( $N$. aerugula, N. atomosa and $N$. estonica) as distinct species is fully justified also from the genetic point of view. 


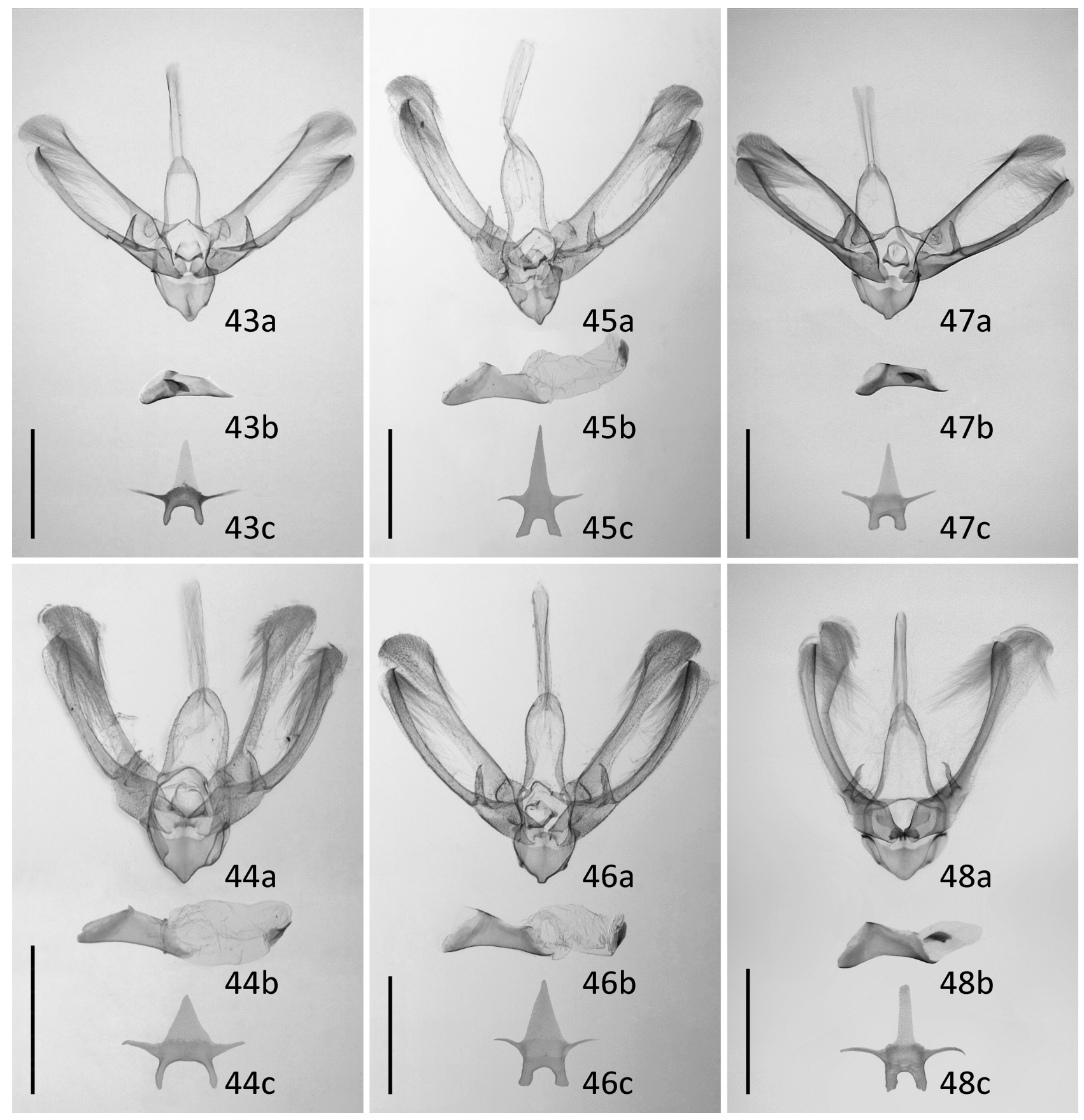

FIGURES 43-48. Male genitalia of Nola spp. 43. Nola estonica sp. nov., PARATYPE, Estonia, Piusa Railway Station, 03.08.2020, TUZ300286 (barcoded). 44. Nola estonica sp. nov., Russia, Iverskii zakaznik, 18.06.-01.07.2010, coll. ZISP. 45. Nola atomosa stat. rev., LECTOTYPE, Russia, Amur region, slide Matov 0588, coll. ZISP. 46. Nola atomosa stat. rev., Russia, Vinogradovka, 19.-20.07.1929, slide Matov 0592, coll. ZISP. 47. Nola aerugula, Estonia, Piilse, 14.-20.07.2019, IZBE1137196. 48. Nola aerugula, HOLOTYPE of Celama centonalis f. alfkeni, Germany, Borkum, 07.1924, ZMH 833303. a. genital armature. b. aedeagus (with vesica everted in 44-46, semi-everted in 48). c. 8th tergite. Scale: $1 \mathrm{~mm}$. 


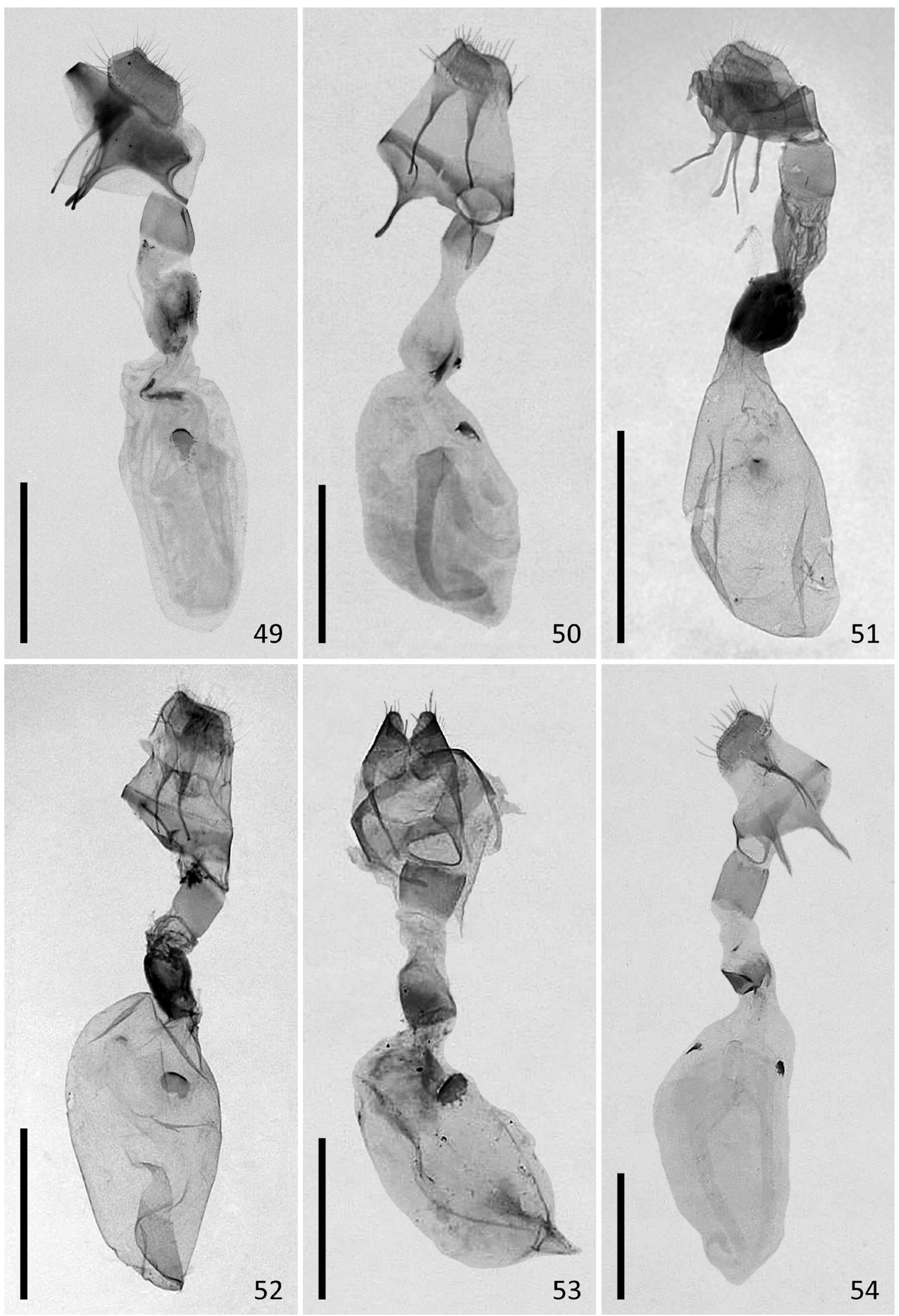

FIGURES 49-54. Female genitalia of Nola spp. 49. Nola estonica sp. nov., HOLOTYPE, Estonia, Piusa Railway Station, 03.08.2020, TUZ300299. 50. Nola estonica sp. nov., PARATYPE, Estonia, Piusa Railway Station, 03.08.2020, TUZ300300. 51. Nola estonica sp. nov., South Korea, Mt. Samaksan, 25.06.2016, MNU genital slide no. 1172, coll. MNU (barcoded). 52. Nola atomosa stat. rev., South Korea, Jindong-ri, 20.06.2017, MNU genital slide no. 1171, coll. MNU (barcoded). 53. Nola atomosa stat. rev., Russia, valley of Izvilinka River, 08.-09.07.1976, IZBE0106556, slide J. Viidalepp 2402. 54. Nola aerugula, Estonia, Sonda, 03.07.1937, IZBE1136200. Scale: $1 \mathrm{~mm}$. 


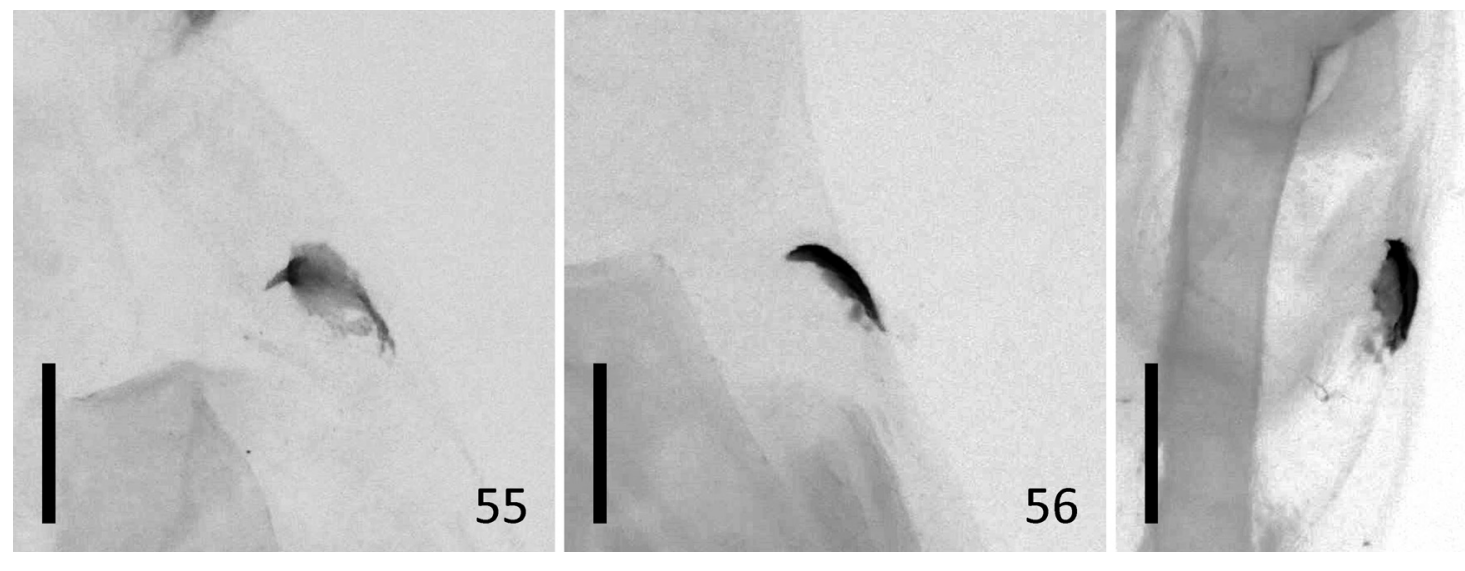

FIGURES 55-57. Ventral signum of female Nola spp. 55. Nola estonica sp. nov., PARATYPE, Estonia, Piusa Railway Station, 03.08.2020, TUZ300300. 56. Nola atomosa stat. rev., Russia, Kedrovaja Pad, 02.-17.08.1977, IZBE0106557. 57. Nola aerugula, Estonia, Vanajärvesoo, 06.07.1995, RCEÕ. Scale: $200 \mu \mathrm{m}$.

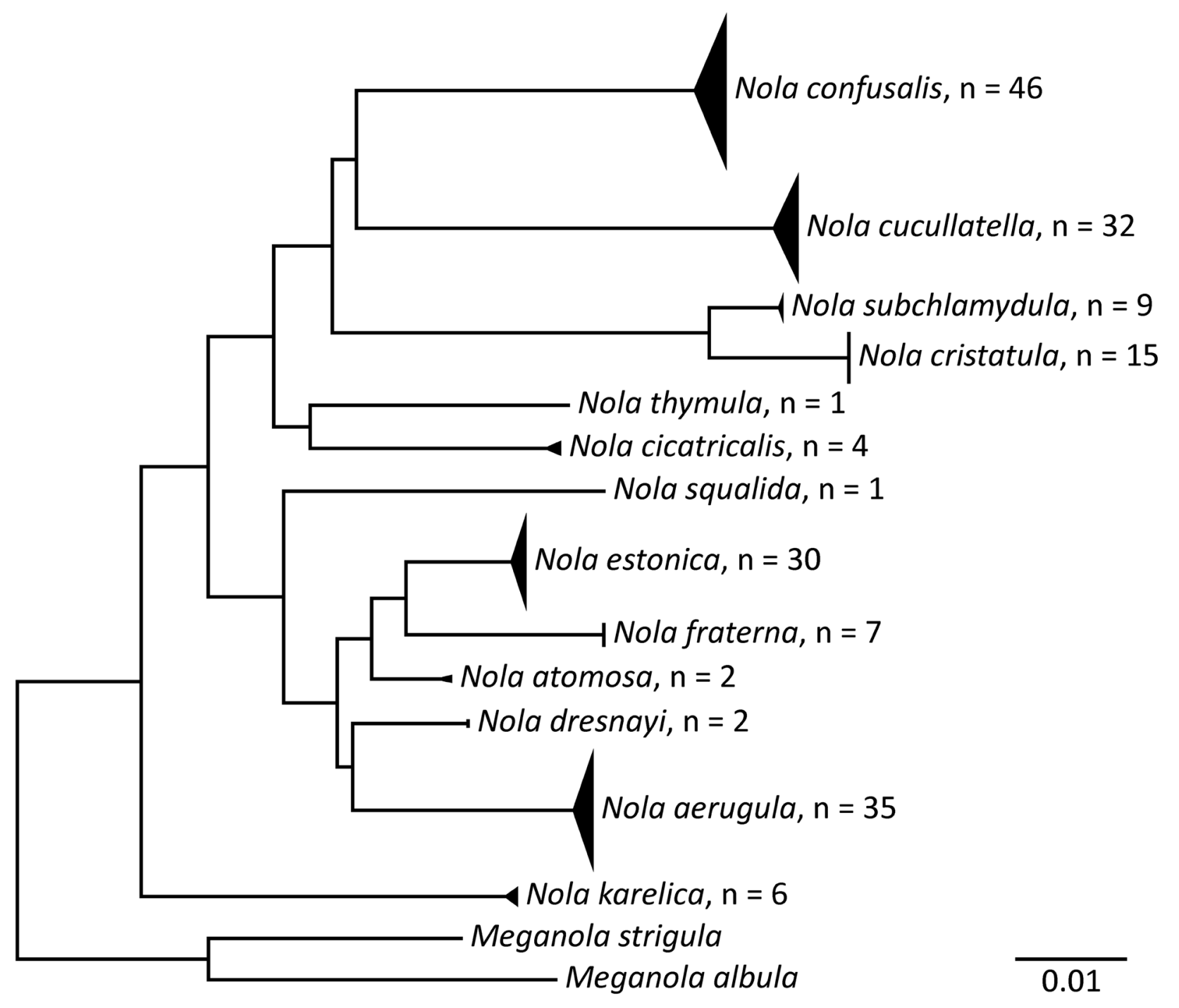

FIGURE 58. Neighbor-joining tree of DNA barcode data of Nola spp. 


\section{Discussion}

The present study shows that there are three species within the paraphyletic entity previously united under the name Nola aerugula. In Europe, $N$. aerugula coexists with the previously unrecognized $N$. estonica. In the Far East, $N$. estonica is sympatric with $N$. atomosa, the latter taxon being here reinstated to the status of a species distinct from $N$. aerugula. While it appears clear that the taxon described here as $N$. estonica has not earlier been recognized in such a taxonomic and geographical scope as presented in the current paper, it cannot be a priori excluded that the type material of some other taxon may belong to this species. Such taxa may currently be treated as synonyms of other species or may have been assigned an intraspecific rank. Indeed, for the externally variable $N$. aerugula numerous aberrations have been described, and possible confusion with some other species should also be considered.

First and foremost, forms with light-coloured wings and reduced pattern are primary suspects for possible confusion with N. estonica. Celama centonalis f. alfkeni Warnecke, 1938, currently treated as a form of N. aerugula, is one such taxon. According to Warnecke's (1938) description (forewings clear white without any transverse lines; only dark tufts of scales in the middle area and brown stripes or dots on costa are visible), f. alfkeni may be suspected to be conspecific with N. estonica. In external appearance, the type material of f. alfkeni (Figure 36) is indeed remarkably similar to some forms of $N$. estonica with a very strongly reduced wing pattern (Figures 5, 15). Nevertheless, the genitalia of the male holotype of f. alfkeni unequivocally demonstrate that this taxon is different from N. estonica, and appears conspecific with $N$. aerugula. In particular, its vinculum (Figure 48a) is much shorter than that of $N$. estonica (Figures 43a, 44a), and the anterior projections of the 8 th tergite of f. alfkeni are wide and located close to each other (Figure 48c), not narrow and apart from each other as in N. estonica (Figures 43c, 44c). Moreover, though we were not able to secure fresh material of particularly light-coloured specimens of $N$. aerugula for sequencing DNA barcodes, public data downloaded from the BOLD database indicate that such individuals have been studied elsewhere. In particular, specimen RMNH.INS.538621, collected from the western coast of the Netherlands, fully matches the description of $C$. centonalis f. alfkeni, but despite that, it has COI haplotype typical to $N$. aerugula.

Other synonyms or infrasubspecific subdivisons of $N$. aerugula we are aware of do not match with $N$. estonica having a different external morphology: Pyralis centonalis Hübner, 1796 has forewings suffused with pale yellow and the transverse lines are much more clear than in N. estonica; Hercyna scabralis Eversmann, 1842 has as strong and dark pattern as typical N. aerugula; Nola littoralis Paux, 1901 has much darker wings than N. estonica; Nola centonalis ab. fasciata Rebel, 1910 has the entire medial area unicolourous light brown; Nola centonalis ab. fumosa Berger, 1918 and Nola centonalis ab. spitzi Schawerda, 1921 have completely unicolourous brown forewings; in Celama centonalis f. aurea Lucas, 1959 all normally brown markings of the forewing have been replaced by yellowish brown ones.

Nola holsatica Sauber, 1916 is a sister taxon of $N$. aerugula, which has a rather restricted range on the coastal parts of Belgium, the Netherlands, northwestern Germany and southwestern Denmark (Fibiger et al. 2009). The taxonomic status of $N$. holsatica has been disputed since its description. Originally it was described as $N$. centonalis var. holsatica (Sauber, 1916), differing from typical form by smaller size, sharper forewing apex and a dark medial line on the upperside of the hindwings. Subsequent authors have sometimes treated holsatica as a subspecies of aerugula (e. g. Heydemann 1934, Fibiger \& Karsholt 1998) but the more widely accepted view is that it is a distinct species (Lempke 1938, de Freina \& Witt 1987, Fibiger et al. 2009, Hacker et al. 2012). The very dark and well expressed pattern of the forewing of $N$. holsatica (for figures including the lectotype, see Fibiger et al. 2009) strongly differs from that of $N$. estonica. The genitalia of $N$. holsatica have been figured by e.g. de Freina \& Witt (1987) and Fibiger et al. 2009, the latter authors explicitly stating that the females possess two signa in the bursa copulatrix. As there is just one signum in the bursa copulatrix of N. estonica (Figures 49-51), it appears undeniable that this species cannot be conspecific with $N$. holsatica. This view is further supported by the report by Aarvik et al. (2017) that the DNA barcodes of $N$. holsatica and N. aerugula are 'almost identical', whereas there is a large (in average 0.042) genetic distance between the DNA barcodes of $N$. aerugula and $N$. estonica.

As is the case with the closely related $N$. aerugula, several intraspecific divisions of $N$. holsatica have been described. First, Celama centonalis ssp. contrarialis Heydemann, 1934 is currently treated as a synonym of $N$. holsatica (Fibiger et al. 2009). These moths are characterized by the absence of the dark transverse line on the upperside of the hindwing, but the pattern of the forewings is as clear and dark as that of typical $N$. holsatica (for figures, see Heydemann 1934). Second, three infrasubspecific subdivisions, published as aberrations of Celama 
holsatica, are also known: ab. reducta Lempke, 1938, ab. fasciata Lempke, 1938 and ab. obscura Lempke, 1938. The original publication by Lempke (1938) is illustrated with photos of material which indicate that all these forms have a much darker pattern on the forewings than N. estonica, and have a transverse band on the upperside of the hindwings that is lacking in $N$. estonica. Therefore, we see no reason to suspect that any of those taxa are conspecific with $N$. estonica.

For $N$. atomosa, which is sympatric with $N$. estonica in the eastern part of the range of the latter species, we are aware of two synonyms. Specimens with a conspicuously dark brown medial area of the forewing were described as a separate species on two occasions: as Nola candidalis Staudinger, 1892 and as Nola shin Inoue, 1982. To our knowledge, forms with a completely dark medial area of the forewing (Fig. 24) do not occur in N. estonica, thus neither $N$. candidalis nor $N$. shin can be conspecific with this newly described species.

Nola dresnayi appeared as a sister taxon to $N$. aerugula in the phylogenetic analysis of DNA barcodes (Figure 58), though based on actual genetic distances its closest relative is $N$. atomosa. $N$. dresnayi has recently been figured by both Fibiger et al. (2009) and Hacker et al. (2012). The grey ground colour of the forewings differentiates $N$. dresnayi from $N$. estonica, and its completely grey hindwings are markedly different from the white hindwings of the latter. Clear differences can be found also in the genitalia: the long, spine-like cornutus of male $N$. dresnayi significantly differs from the short and wide cornutus of $N$. estonica. According to Fibiger et al. (2009), the females of $N$. dresnayi are characterized by having just one signum in the bursa copulatrix, sharing this character with $N$. estonica. However, the posterior strongly sclerotized part of ductus bursae of $N$. dresnayi is about two times longer than wide (Fibiger et al. 2009), whereas in N. estonica it is shorter than wide (Figures 49-51).

Nola duercki (Zerny, 1935) is a northwestern African species that has been figured by de Freina \& Witt (1987) and more recently by Hacker et al. (2012). This species is characterized by pale fore- and hindwings, with a rather straight dark postmedial line of the forewing being the most prominent element of the wing pattern. The male genitalia of $N$. duercki, figured by Hacker et al. (2012), are easily distinguished from those of $N$. estonica by distinctly shorter valvae, which have both dorsal and ventral lobes wider than those of the latter species. Females of N. duercki are unknown (de Freina \& Witt 1987, Hacker et al. 2012).

Nola enphaea (Hampson, 1901) is a little known Chinese species that resembles $N$. dresnayi. The original description (Hampson 1901) did not illustrate the species, but the subsequent treatment by Hampson (1914) is accompanied by a colour drawing that matches the description well. The grey colouration of the body and both foreand hindwings of the moths indicates that $N$. enphaea cannot be confused with $N$. estonica.

In the analysis of genetic data, Nola fraterna clustered as sister to $N$. estonica (Figure 58). Such a placement was surprising, as $N$. fraterna is classified as belonging to the pumila-fraterna group sensu Làszlo et al. (2014). This unexpected result may be explained by the fact that DNA barcodes alone are unsuitable for large-scale phylogenetic analyses due to saturation (summarized in DeSalle \& Goldstein 2019), though their usefulness in solving specieslevel taxonomic questions is beyond doubt (Hebert \& Gregory 2005, Miller et al. 2016). In any case, the fact that $N$. fraterna clustered as sister to $N$. estonica further supports our conclusion that the latter taxon truly is a species distinct from both $N$. aerugula and $N$. atomosa that had so far remained undetected. The possibility that $N$. fraterna is conspecific with $N$. estonica can be excluded beyond reasonable doubt: in addition to the large genetic distance (on average 0.029), these species are very different externally. Specifically, the wings of $N$. fraterna are dark grey with a black, strongly curved antemedial line of the forewing being the most prominent element of the wing pattern (for illustrations, see Hampson 1914, Inoue 1998, Holloway 2003), whereas the wings of N. estonica are white and the antemedial line on its forewing is never darker than the postmedial line (Figures 1-18).

In summary, we are currently unaware of any previously described taxa potentially synonymous with $N$. estonica. The possibility that we have overlooked a described taxon which is synonymous with $N$. estonica appears to be low, considering the number of thorough revisions incorporating the genus Nola that have become available within the last few decades (Fibiger et al. 2009, Hacker et al. 2012, László et al. 2014).

In the Far East, based on specimens examined, N. estonica appears to be rather widely distributed from South Korea to the Amur region of Russia. Moreover, in NCBI GenBank there is a COI sequence of Nola from an undisclosed locality in China (MT785500), which, being almost identical to haplotypes of $N$. estonica from South Korea, should be attributed to this species. Nevertheless, as far as it can be judged, N. estonica is less common than N. atomosa in the Primorsky Region of Russia. The data for South Korea are currently too preliminary to tell which species is more widespread, but both are known to occur in the northeastern part of the country.

The known European distribution of $N$. estonica is currently limited to Estonia. All specimens but one have 
been recorded in the southeastern part of the country, where the existence of permanent populations is beyond doubt. However, some of the known localities are situated just a few kilometers away from northeastern Latvia and the western border of the Pskov Region of Russia, making the presence of $N$. estonica in those regions very likely.

The data currently available thus point at the possibility that $N$. estonica may have a disjunct distribution, with the East European and the East Asian populations being separated by at least 6000 kilometers. Such a biogeographic pattern is not unprecedented, represented by e.g. Catocala electa (Vieweg, 1790) (Erebidae) and Craniophora ligustri ([Denis \& Schiffermüller], 1775) (Noctuidae). However, the lepidopterans showing such a distribution pattern tend to be nemoral species feeding on hardwood trees, which follow the disjunct distribution of their host plants. The known habitat preference of $N$. estonica in Estonia (pine forest or dry meadow on sandy soil) does not support this scenario. It therefore appears more likely that $N$. estonica has a broad transpalaearctic distribution and its occurrence in the vast territory separating the known populations just remains to be confirmed.

The oldest available Estonian record of N. estonica dates from 2001, and the species could thus be a newcomer in the Estonian fauna. This does not appear impossible, as, in addition to the influx of southern lepidopterans associated with the climate change (Tiitsaar et al. 2019, Jürivete and Õunap 2020), some eastern moth species-such as Eversmannia exornata (Eversmann, 1837) (Uraniidae) and Calyptra thalictri (Borkhausen, 1790) (Erebidae) — have also colonized the country during the past 20 years. Nevertheless, it is premature to judge the history of $N$. estonica in the region before all historical collections in Estonia and neighboring countries have been thoroughly studied. We thus encourage lepidopterists to carefully examine unusually light specimens of $N$. aerugula and $N$. atomosa to reveal the actual distribution of Nola spp. in both the Western and Eastern Palaearctic region, respectively. If DNA barcoding would appear impractical due to e.g. the age of the specimen, female genitalia provide the most reliable means of identification.

\section{Acknowledgements}

This study was supported by the Estonian Research Council grant PRG741. Sei-Woong Choi is thankful to a grant from the National Institute of Biological Resources (NIBR), funded by the Ministry of Environment (MOE) of the Republic of Korea (NIBR202102204). The work of Alexey Matov was performed in the frames of the state research project AAAA-A19-119020690101-6. The authors thank Mr. Sung-Soo Kim for providing specimens from South Korea for analysis, Dr. Imre Taal and Mr. Andro Truuverk for loaning their Estonian moths for study, as well as Dr. Thomas Simonsen and Per Falck for images of the Danish material. We appreciate Dr. Villu Soon's help in photographing the specimens from Estonian collections. Dr. Martin Husemann and Dr. Thure Dalsgaard kindly loaned us the type material stored in coll. ZMH. Last but not least, we thank Dr. Jaan Viidalepp and Dr. Olavi Kurina for their constructive comments, Dr. R. Davis for helping to improve the language of the manuscript, and Dr. Reza Zahiri for his help both before and after the submission of the manuscript.

\section{References}

Aarvik, L., Bengtsson, Å., B., Elven, H., Ivinskis, P., Jürivete, U., Karsholt, O., Mutanen, M. \& Savenkov, N. (2017) NordicBaltic Checklist of Lepidoptera. Norwegian Journal of Entomology, Supplement 3, 1-236.

Da, W., Wang, M. \& Hu, Y.-Q. (2021) Description of a new species and a new record of the genus Nola Leach, 1815 (Lepidoptera, Nolidae, Nolinae) from Tibet, China. Zootaxa, 4926 (2), 293-295. https://doi.org/10.11646/zootaxa.4926.2.9

De Freina, J.J. \& Witt, T.J. (1987) Die Bombyces und Sphinges der Westpalaearktis (Insecta, Lepidoptera). Band 1. Edition Forschung \& Wissenschaft Verlag GmbH, München, 708 pp.

DeSalle, R. \& Goldstein, P. (2019) Review and interpretation of trends in DNA barcoding. Frontiers in Ecology and Evolution, $7,302$. https://doi.org/10.3389/fevo.2019.00302

Eversmann, E. (1842) Quaedam lepidopterorum species novae, in Rossia orientali observatae, nunc describae et depictae. Bulletin de la Société Impériale des Naturalistes de Moscou, 15, 543-565.

Fibiger, M. \& Karsholt, O. (1998) First records of Nola harouni from Europe and comments on the taxonomic status of $N$. centonalis holsatica (Nolidae). Nota Lepidopterologica, 21, 194-205.

Fibiger, M., Ronkay, L., Steiner, A. \& Zilli, A. (2009) Noctuidae Europaeae. Vol. 11. Pantheinae, Dilobinae, Acronictinae, 
Eustrotiinae, Nolinae, Bagisarinae, Acontiinae, Metoponiinae, Heliothinae, and Bryophilinae. Entomological Press, Sorø, $504 \mathrm{pp}$.

Folmer, O., Black, M., Hoeh, W., Lutz, R. \& Vrijenhoek, R. (1994) DNA primers for amplification of mitochondrial cytochrome c oxidase subunit I from diverse metazoan invertebrates. Molecular Marine Biology and Biotechnology, 3, $294-299$.

Hampson, G.F. (1901) New species of Syntomidae and Arctiadae. The Annals and Magazine of Natural History, including Zoology, Botany and Geology, 45, 165-186.

Hampson, G.F. (1914) Catalogue of the Lepidoptera Phalaenae in the British Museum. Supplement. Vol. 1. Catalogue of the Amatidae and Arctiadae (Nolinae and Lithosianae) in the collection of the British Museum. Printed by Order of the Trustees, London, $858 \mathrm{pp}$.

Hacker, H., Schreier, H.-P. \& Goater, B. (2012) Revision of the tribe Nolini of Africa and Western Palaearctic Region (Lepidoptera, Noctuoidea, Noctuidae, Nolinae). Esperiana, 17, 1-614.

Hall, T.A. (1999) BioEdit: a user-friendly biological sequence alignment editor and analysis program for Windows 95/98/NT. Nucleic Acids Symposium Series, 41, 95-98.

Hebert, P.D., Penton, E.H., Burns, J.M., Janzen, D.H. \& Hallwachs, W. (2004) Ten species in one: DNA barcoding reveals cryptic species in the neotropical skipper butterfly Astraptes fulgerator. Proceedings of the National Academy of Sciences of the United States of America, 101, 14812-14817. https://doi.org/10.1073/pnas.0406166101

Hebert, P.D.N. \& Gregory, T.R. (2005) The promise of DNA barcoding for taxonomy. Systematic Biology, 54, 852-859. https://doi.org/10.1080/10635150500354886

Heydemann, F. (1934) Einige für Schleswig-Holstein beachtenswerte oder neue Lepidopteren. Internationale Entomologische Zeitschrift, 27, 417-422.

Holloway, J. D. (2003) The Moths of Borneo. Part 18. Nolidae. Southdene Sdn. Bhd. Kuala Lumpur, 279 pp.

Inoue, H. (1998) Nolinae (Noctuidae) from Nepal. Moths of Nepal. Part 5. Tinea, 15 (Supplement 1), 89-98.

Jürivete, U. \& Õunap, E. (2020) Estonian Lepidoptera. Catalogue. Eesti Lepidopteroloogide Selts, Tallinn, 192 pp.

Kristensen, N.P. (1999) 4. Skeleton and muscles: adults. In: Kristensen, N.P. (Ed.), Lepidoptera, Moths and Butterflies. Vol. 2. Morphology, Physiology and Development. Handbook of Zoology IV. Arthropoda: Insecta. Part 36. Walter de Gruyter, Berlin and New York, pp. 39-131. https://doi.org/10.1515/9783110893724.39

László, G.M., Ronkay, G. \& Ronkay, L. (2014) Taxonomic studies on the genus Nola Leach, 1815 (Lepidoptera, Noctuoidea, Nolidae, Nolini). Fibigeriana Supplement, 2, 201-262.

Lempke, B.-J. (1938) Celama centonalis Hb. et Celama holsatica Sauber. Lambillionea, 38, 27-38.

Matov, A. Yu. (2019) Nolidae. In: Sinev, S. Yu. (Ed.), Catalogue of the Lepidoptera of Russia. Zoological Institute RAS. St. Petersburg. pp. 317-319.

Miller, S.E., Hausmann, A., Hallwachs, W. \& Janzen, D.H. (2016) Advancing taxonomy and bioinventories with DNA barcodes. Philosophical Transactions of the Royal Society B - Biological Sciences, 371, 20150339. https://doi.org/10.1098/rstb.2015.0339

Nupponen, K. \& Fibiger, M. (2006) Additions and corrections to the list of Bombyces, Sphinges and Noctuidae of the Southern Ural Mountains. Part I. (Lepidoptera: Lasiocampidae, Lemonidae, Sphingidae, Notodontidae, Noctuidae, Pantheidae, Lymantriidae, Nolidae, Arctiidae). Esperiana, 12, 167-195.

Oh, S.-H. (2001) A Review of the Subfamily Nolinae (Lepidoptera, Noctuidae) in Korea (I): Genus Nola Leech. Insecta Koreana, $18,123-137$.

Ounap. E., Viidalepp, J. \& Saarma, U. (2005) Phylogenetic evaluation of the taxonomic status of Timandra griseata and T. comae (Lepidoptera: Geometridae: Sterrhinae). European Journal of Entomology, 102, 607-615. https://doi.org/10.14411/eje.2005.085

Õnap, E., Viidalepp, J. \& Saarma, U. (2008) Systematic position of Lythriini revised: transferred from Larentiinae to Sterrhinae (Lepidoptera, Geometridae). Zoologica Scripta, 37, 405-413. https://doi.org/10.1111/j.1463-6409.2008.00327.x

Sauber, A. (1916) Nola centonalis Hb. n. var. holsatica. Internationale Entomologische Zeitschrift, $10,97$.

Sasaki, A. (2011) Nolidae. In: Kishida, Y. (Ed.), The Standard of Moths in Japan II. Gakken Education Publishing, Tokyo, pp. 170-189.

Sinev, S.Yu., Anikin, V.V. \& Zolotuhin, V.V. (2017) Volgo-Ural Pyraloidea and Pterophoridae described by E. Eversmann. In: Anikin, V.V., Sachkov, S.A. \& Zolotuhin, V.V. (Ed.), "Fauna Lepidopterologica Volgo-Uralensis": from P. Pallas to present days. Proceedings of the Museum Witt Munich, 7, pp. 380-386.

Tamura, K., Stecher, G., Peterson, D., Filipski, A. \& Kumar, S. (2013) MEGA6: Molecular Evolutionary Genetics Analysis version 6.0. Molecular Biology and Evolution, 30, 2725-2729. https://doi.org/10.1093/molbev/mst197

Thompson, J.D., Higgins, D.G. \& Gibson, T.J. (1994) ClustalW: improving the sensitivity of progressive multiple sequence alignment through sequence weighting, position specific gap penalties and weight matrix choice. Nucleic Acids Research, $22,4673-4680$. https://doi.org/10.1093/nar/22.22.4673

Tiitsaar, A., Valdma, D., Õunap, E., Remm, J., Teder, T. \& Tammaru, T. (2019) Distribution of butterflies (Lepidoptera: 
Papilionoidea) in Estonia: Results of a systematic mapping project reveal long-term trends. Annales Zoologici Fennici, 56, 147-185.

https://doi.org/10.5735/086.056.0114

Warnecke, G. (1917) Über einige Probleme der Schmetterlingsfauna der ostfriesischen Inseln. Abhandlungen des naturwissenschaftlichen Vereins Bremen, 30, 118-125. 